NBER WORKING PAPER SERIES

THE POLTTICAL ECONOMY OF U.S. EXPORT SUBSIDIES FOR WHEAT

Bruce L. Gardner

Working Paper No. 4747

\author{
NATIONAL BUREAU OF ECONOMIC RESEARCH \\ 1050 Massachusetts Avenue \\ Cambridge, MA 02138 \\ May 1994
}

Helpful comments on this chapter were received from Robert Chambers, Thomas Grennes, Howand Leathers, Erik Lichtenberg, Larry Salathe and Daniel Sumner, as well as participants in the NBER conference at which this chapter was first presented. This paper is part of NBER's research program in International Trade and Investment. Any opinions expressed are those of the author and not those of the National Bureau of Economic Research. 


\title{
THE POLITICAL ECONOMY OF U.S.
} EXPORT SUBSIDIES FOR WHEAT

\begin{abstract}
During 1985-93 the U.S. Government provided \$4.9 billion in subsidies to targeted foreign buyers of U.S. wheat under its Export Enhancement Program (EEP). The subsidies averaged \$31 per metric ton, or about 25 percent of the U.S. price. The EEP generates a small gain to U.S. farmers, compared to its costs. Lacking a clear economic justification, the debate on the EEP indicates the following were the key factors in its political success: farmers and agribusiness have been unified in support of the program, and have excellent political channels through which to express their views; domestic users of wheat have not opposed the program; and the program received an initial boost because of its use of large government-owned wheat stocks, allowing it to be treated as budget neutral in Congress. An economic argument that carried political weight was that the EEP, by increasing the costs of the European Community's wheat export subsidies, would encourage them to negotiate joint U.S.JEC subsidy reductions. In fact, the EC in 1993 did agree to multilateral subsidy reductions in the GATT, as well as reforming their own policies unilaterally. But it remains questionable whether this outcome justifies the EEP.
\end{abstract}

Bruce L. Gardner

Department of Agricultural and Resource Economics

University of Maryland

College Park, MD 20742 
The Political Economy of U.S. Export Subsidies for Wheat*

U.S. agricultural commodities are predominantly exported rather than imported, but border price distortions for the exported commodities nonetheless exist, in the form of export subsidies. This paper investigates the economics and politics of export subsidies for the commodity where these subsidies are most important, wheat, and focuses on the Export Enhancement Program initiated in 1985.

\section{Background: Agricultural Price Support Programs}

Systematic programs to support agricultural commodity prices date from the initial New Deal legislation of 1933. Wheat was one of the original "basic" commodities supported (the others were cotton, corn, hogs, rice, tobacco, and milk). ${ }^{1}$ Wheat continues to be one of the most heavily supported commodities. Table 1 shows estimates of transfers to producers of wheat and other commodities during 1984-87, our period of primary concern. Wheat fares well, with $\$ 3.25$ billion in estimated net gains (producers' surplus) annually, 48 percent of the market value of wheat.

'Rye, flax, barley, grain sorghum, cattle, peanuts and sugar (beets and cane) were added in 1934. The only important commodities excluded were poultry and eggs, soybeans, forage crops, fruits and vegetables. A useful, detailed discussion of agricultural policy in the 1930 s is Benedict (1953). 
Table 1. Estimated annual gains from commodity programs: $1984-87$

(1)

Number
of
Producers
(thousands)

wheat

352

corn $\quad 627$

soybeans $\quad 442$

rice $\quad 12$

cotton $\quad 43$

tobacco $\quad 137$

sugar crops 9

peanuts

milk
(2)

Producers' gains

( $\$$ million)
(3)

Market Value of Crop (\$ million)
$(2) \div(3)$

Protection

rate

$\begin{array}{rrr}3,250 & 6,770 & .48 \\ 4,200 & 16,550 & .25 \\ 410 & 10,520 & .04 \\ 460 & 870 & .53 \\ 680 & 3,580 & .19 \\ 360 & 2,310 & .16 \\ 610 & 1,670 & .36 \\ 820 & 1,080 & .76 \\ 1,450 & 18,200 & .08\end{array}$

Sources: (1) U.S. Census of Agriculture, 1987, Vol, I, Part 51; (2) Lin and Gardner (1988); (3) USDA, Agricultural Statistics, 1992. 
The means of support have been predominantly domestic market interventions-government purchases, supply controls, payments to producers-but border measures have inevitably been required to maintain U.S. prices above corresponding world market levels. Commodities imported into the United States - sugar, citrus juices, dairy products, wool, meats - are protected by means of tariffs or quantitative restrictions on imports. But a substantially greater volume of U.S. agricultural output is exported (Figure 1), causing greater difficulty for domestic price support.

Attempts have been made to explain the economic and political forces that result in agricultural price supports generally, and the political economy of differences between the support provided for different commodities. Explanations have focussed on political factors such as the long tenure of mostly rural Southern committee chairmen in Congress, the fact that rural areas are more than proportionally represented in the Senate, and general sympathy for farm people among the nonfarm population (see Benedict, 1953; Hardin, 1968; Bonnen and Browne (1989), Rapp (1988), Browne, et. al. (1992)).

In Gardner (1987), I attempt to explain differences between commodities in the level of support granted. There is not clear evidence that having either a small or large number of producers or being geographically concentrated or dispersed, makes much difference in the degree of protection. But it helps a commodity's political prospects significantly to be an imported product and to have experienced a recent price decline. And it harms a product's prospects to be highly elastic in both supply or demand (making it difficult for either production controls or subsidies to transfer a large amount to producers without generating relatively large deadweight losses). Nonetheless, most of the commodity-to-commodity variation in protection remains 
FIGURE 1. Agricultural Exports Minus Imports

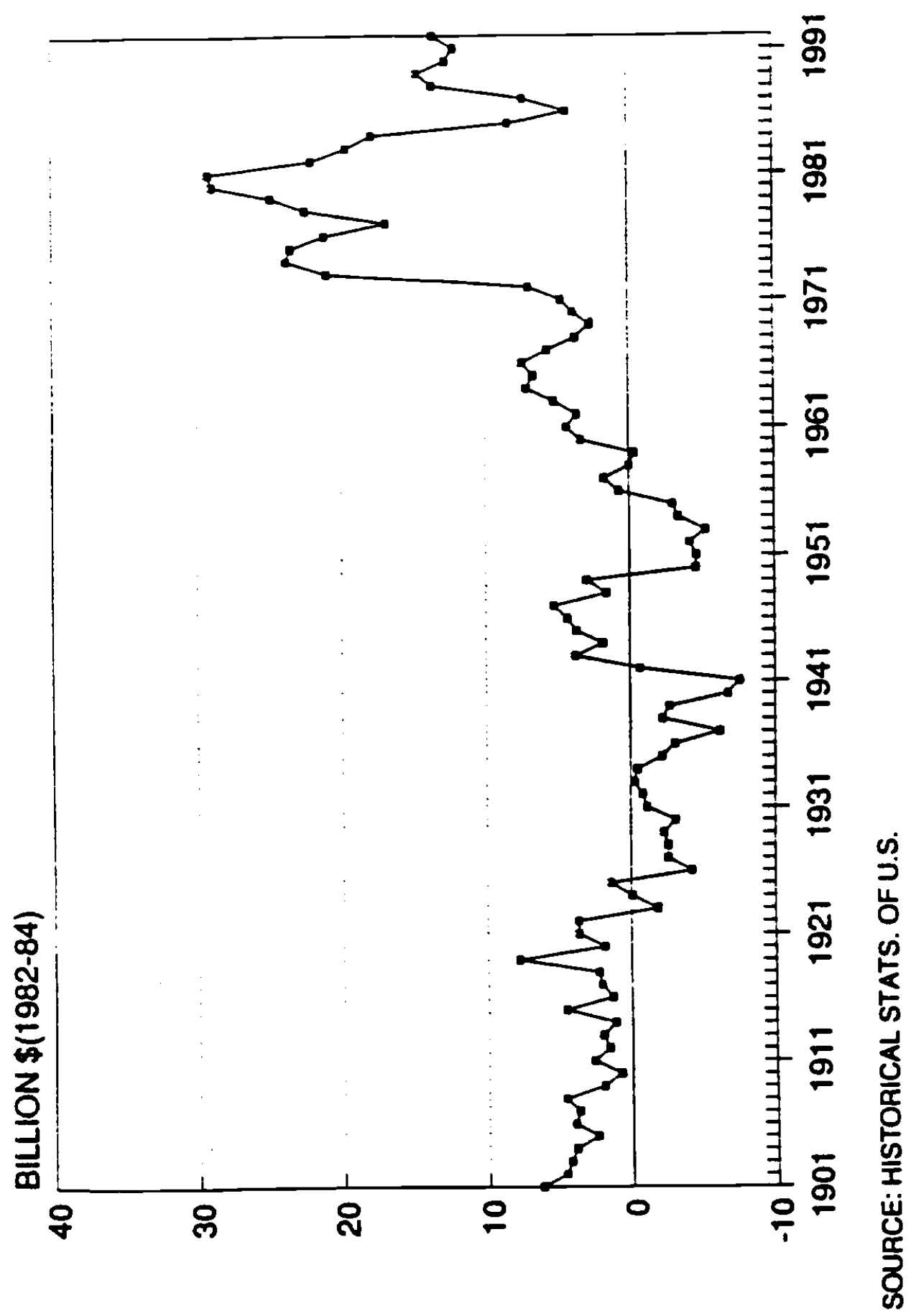


unexplained. Further progress in understanding U.S. agricultural protection may well require more detailed investigation of particular commodity policies.

Wheat trade and the wheat program. Immediately following World War II wheat exports became a large component of the demand for U.S. wheat (Figure 2). In 1950, 35 percent of production was exported, and over half the crop has been exported in 1980-1993. At the same time, wheat prices have been seen by producers as generally too low throughout the postwar period. These concerns have been politically potent enough to maintain Depression-era wheat program mechanisms in place to the present. The new element in the 1950 s was the importance of the export market, and the problems and opportunities this posed for the wheat price-support program.

The traditional means of price support is a governmental agreement, through its Commodity Credit Corporation (CCC), to buy wheat at the support price. This program periodically led to governmental acquisition of large stocks which were costly to store and for which markets did not exist at the support price level. Three main policy instruments have been on the agenda for solving the surplus commodity problem: subsidized sales abroad; acreage reduction programs; and permitting market prices to fall while compensating producers with "deficiency" payments when the market price falls below a legislated target price.

In post-World War II wheat policy, subsidized sales abroad were the first approach tried. Continued foreign donations of wheat were a natural follow-up to the Marshall Plan. They were systematized in the Agricultural Trade and Development Act of 1954 (known as P.L. 480 and, as reformulated in the 1960 s, Food for Peace). At the same time U.S. commercial wheat 
FIGURE 2. U.S. Wheat Trade

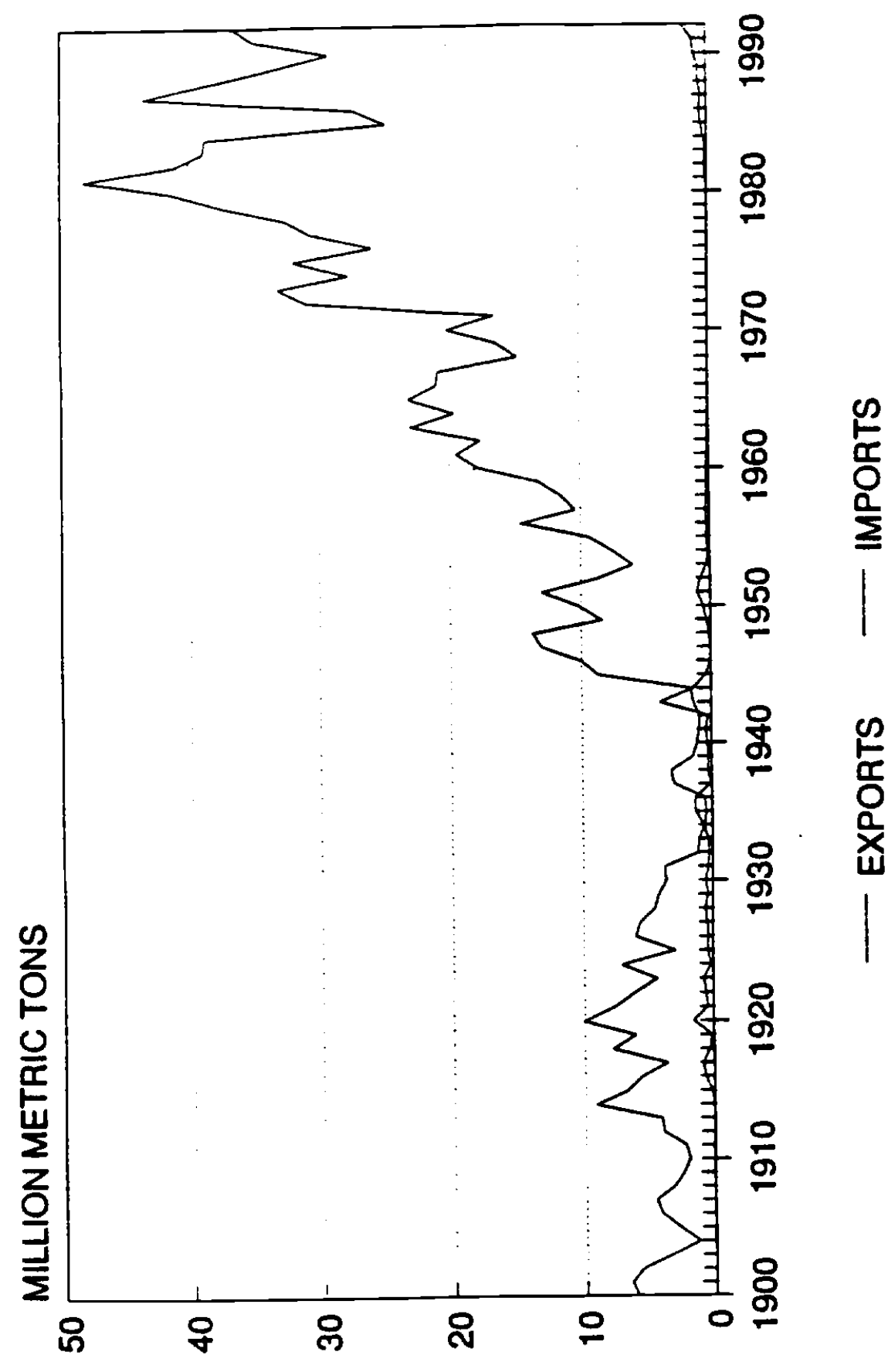

导 
exports were subsidized in the framework of the International Wheat Agreement, under general authority given the Secretary of Agriculture in the 1930s. The subsidy ranged from 5 to 30 percent of the price of wheat, depending on world and U.S. market conditions in each year. The Agricultural Adjustment Act of 1933 (Section 22) gave the President authority, strengthened in the Agricultural Act of 1948 , to impose import quotas if imports threatened the effectiveness of any price-support program. ${ }^{2}$

In the mid-1950s it became apparent that food aid and subsidized commercial exports were insufficient to dispose of U.S. wheat surpluses. Acreage allotments, a feature of the 1930s programs, were re-introduced in 1954 , and reduced planted acreage by about 18 million acres: (from 79 million in 1953 to an average of 61 million in 1954-56). Each producer had to stay under the farm's allotment in order to be eligible for price-support loans. In 1956 the Soil Bank program was introduced. It paid wheat growers about $\$ 20$ per acre (roughly market rental rates) to idle an average of 12 million more acres (20 percent of pre-program acreage) in 1956-58.

In 1964 the approach of letting price supports fall, with compensating payments to producers, was introduced. The support price was cut essentially to the world market-clearing level, with the idea of reducing CCC stocks and the need for export subsidies. At the same time. payments were made to guarantee higher farmer receipts for that fraction of the wheat crop sold domestically. Each producer received a "domestic allotment" for purposes of calculating this payment.

\footnotetext{
${ }^{2}$ Small quantities of wheat imports were grandfathered in by a lower limit of the wheat import quota at 50 percent of the quantity imported in a base period determined by the President. The wheat imports shown in figure 2 are from Canada. Section 22 quotas were suspended by Executive Order in 1974, but a recent increase in U.S. imports of Canadian wheat has led to calls for their re-imposition.
} 
Acreage idling, payments, and export subsidies all remained in place until the commodity boom that erupted with the large Soviet wheat purchases of July 1972. During 1973-76 market prices were well above support levels. The conflation of Soviet purchases, the oil shock, income growth in food importing countries, and accelerating U.S. inflation convinced many that a watershed had been crossed that meant an end to the era of agricultural surpluses. Acreage reduction programs were abandoned and farmers were encouraged, in the Secretary of Agriculture's phrase, to plant fencerow to fencerow. The Nixon Administration went so far as to replace export subsidies by quantitative limitations on exports to Eastern Europe and the Soviet Union in 1974-76.

By late 1976 the boom mentality had begun to fade, for wheat before any other major crop. In October 1976 President Ford, at the urging of Senator Dole and others, raised the CCC loan rate for wheat from $\$ 1.37$ to $\$ 2.25$ per bushel. President Carter was confronted within a year of taking office by a tractorcade, led by wheat growers, that resulted in legislation that resurrected the traditional wheat policy instruments. However, sustained intervention on the pre1972 scale did not reappear until the mid-1980s. See table 2 for a summary of indicators.

The remainder of this paper will focus on events before and after the reintroduction of export subsidies in the Export Enhancement Program (EEP), initiated in 1985 and still functioning. The discussion will consider: the economics of EEP and alternative interventions in 1985, the interest group mobilization that caused the EEP to succeed politically, the arguments employed and the political channels used. Finally, there will be an assessment of the consequences of the program. 
Table 2: Wheat Policy Instruments, 1960-1990

\begin{tabular}{|c|c|c|c|}
\hline $\begin{array}{l}\text { Crop } \\
\text { Year }\end{array}$ & $\begin{array}{l}\text { Government } \\
\text { Inventory } \\
\text { (Mil. Bu.) }\end{array}$ & $\begin{array}{l}\text { Government } \\
\text { Payments } \\
\text { (Mil. dol.) }\end{array}$ & $\begin{array}{c}\text { Acreage } \\
\text { Diversion } \\
\text { (Mil. acres) }\end{array}$ \\
\hline 1960 & 1280 & 0 & 0 \\
\hline 1961 & 1134 & 0 & 10.2 \\
\hline 1962 & 1111 & 286 & 10.7 \\
\hline 1963 & 839 & 243 & 7.1 \\
\hline 1964 & 646 & 443 & 5.1 \\
\hline 1965 & 343 & 509 & 7.1 \\
\hline 1966 & 132 & 681 & 8.2 \\
\hline 1967 & 102 & 727 & 0 \\
\hline 1968 & 163 & 746 & 0 \\
\hline 1969 & 301 & 856 & 11.0 \\
\hline 1970 & 378 & 871 & 15.7 \\
\hline 1971 & 380 & 886 & 13.5 \\
\hline 1972 & 155 & 859 & 20.1 \\
\hline 1973 & 19 & 478 & 7.3 \\
\hline 1974 & 1 & 102 & 0 \\
\hline 1975 & 0 & 51 & 0 \\
\hline 1976 & 0 & 143 & 0 \\
\hline 1977 & 390 & 1157 & 0 \\
\hline 1978 & 454 & 719 & 9.6 \\
\hline 1979 & 448 & 72 & 8.2 \\
\hline 1980 & 560 & 228 & 0 \\
\hline 1981 & 750 & 635 & 0 \\
\hline 1982 & 1253 & 489 & 5.8 \\
\hline 1983 & 799 & 1080 & 30.0 \\
\hline 1984 & 1032 & 1556 & 18.4 \\
\hline 1985 & 1198 & 2208 & 18.8 \\
\hline 1986 & 1462 & 3673 & 21.0 \\
\hline 1987 & 750 & 3290 & $28.1^{*}$ \\
\hline 1988 & 477 & 1686 & $29.6^{*}$ \\
\hline 1989 & 267 & 724 & $18.4^{*}$ \\
\hline 1990 & 177 & 2420 & $17.8^{*}$ \\
\hline 1991 & 202 & 2245 & $26.0^{*}$ \\
\hline 1992 & 178 & 1370 & $17.9^{*}$ \\
\hline
\end{tabular}

Source: USDA, Agricultural Stabilization and Conservation Service

* Includes wheat base placed in the Conservation Reserve Program under 10-year contracts (10.6 million acres in 1992). 


\section{Origins of the Export Enhancement Program}

Agriculture in general faced severe economic problems in the early 1980s. The problens are apparent in the data on farm income and the farm sector's balance sheet. Real farm income (including government assistance) in 1980-84 averaged about half its level in 1971, before the commodity boom (figure 3). The USDA's estimate of farm equity, the value of farm assets minus liabilities, declined from $\$ 1.8$ trillion (1987 dollars) on January 1,1979 to one-third of that value, \$0.6 trillion on January 1, 1985.

With respect to wheat growers more specifically there are no data on income or equity value, but an indication that is particularly useful in political terms can be obtained from statelevel statistics. Kansas and North Dakota are the two most important wheat states, the centers of the winter and spring wheat growing areas, respectively. Together they account for about 30 percent of U.S. wheat acreage. Within these states, 46 percent of Kansas cropland and 45 percent of North Dakota cropland is planted to wheat, In both states, real farm equity declined sharply after 1979 (figure 4), at about the same rate as in the nation as a whole. Figure 5 shows the real price of cropland in Kansas and the United States, again both declining sharply.

These indicators are sufficient (but perhaps not necessary) conditions to explain cries of economic pain from the wheat growers. The Wheat Program as revised in the Agriculture and Food Act of 1981 involved considerable government efforts to assist wheat producers. The price paid to farmers for wheat placed in government ownership was increased to $\$ 4.00$ per bushel for the 1982 crop. It had been only $\$ 1.37$ up to 1975 . U.S. wheat acreage planted expanded $45 \%$, from $\$ 59$ million acres in 1973 to 86 million acres in 1982, and USDA increased its wheat stocks 
FIGURE 3. U.S. Farm Income

100 S bilkions

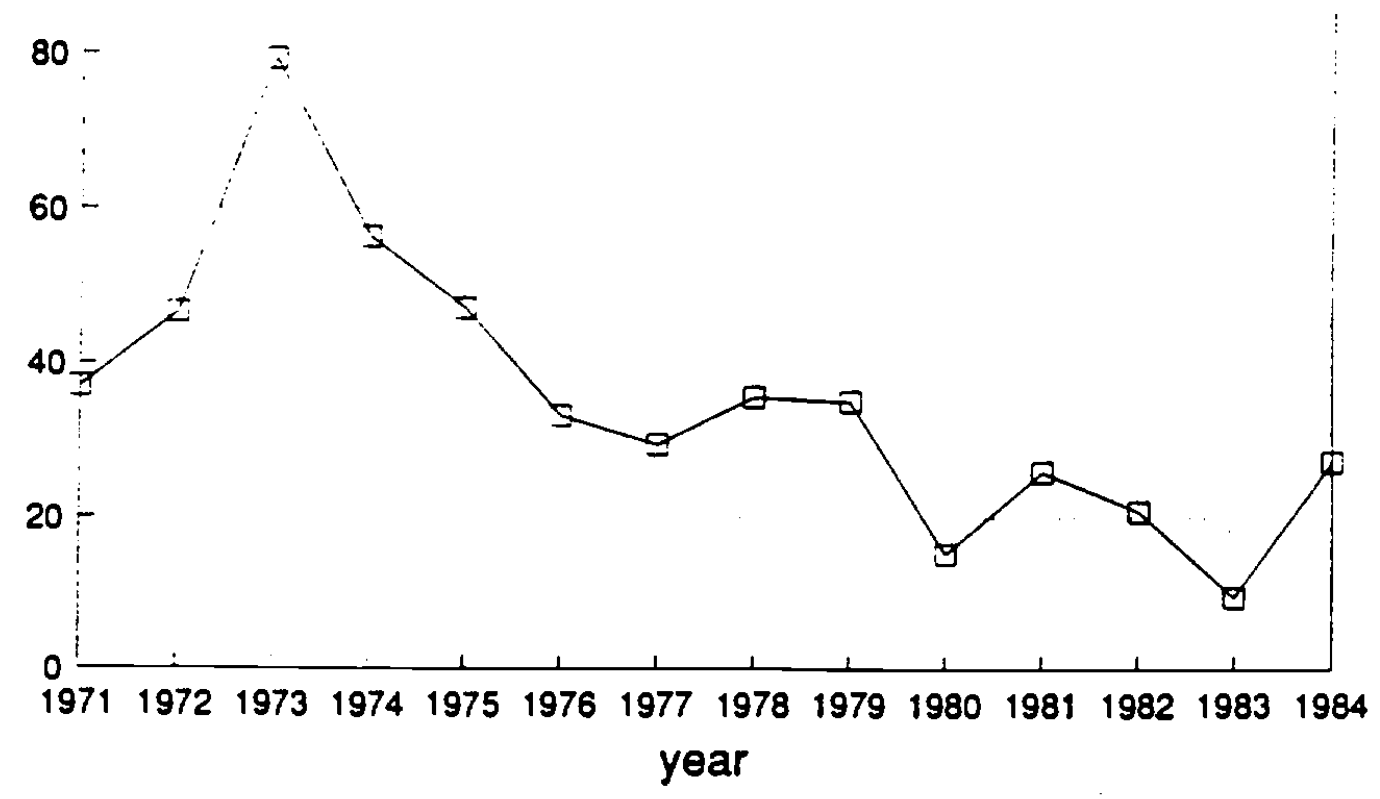

1987 dollars 
FIGURE 4. Equity in Farms Value of Assets Minus Liabilities

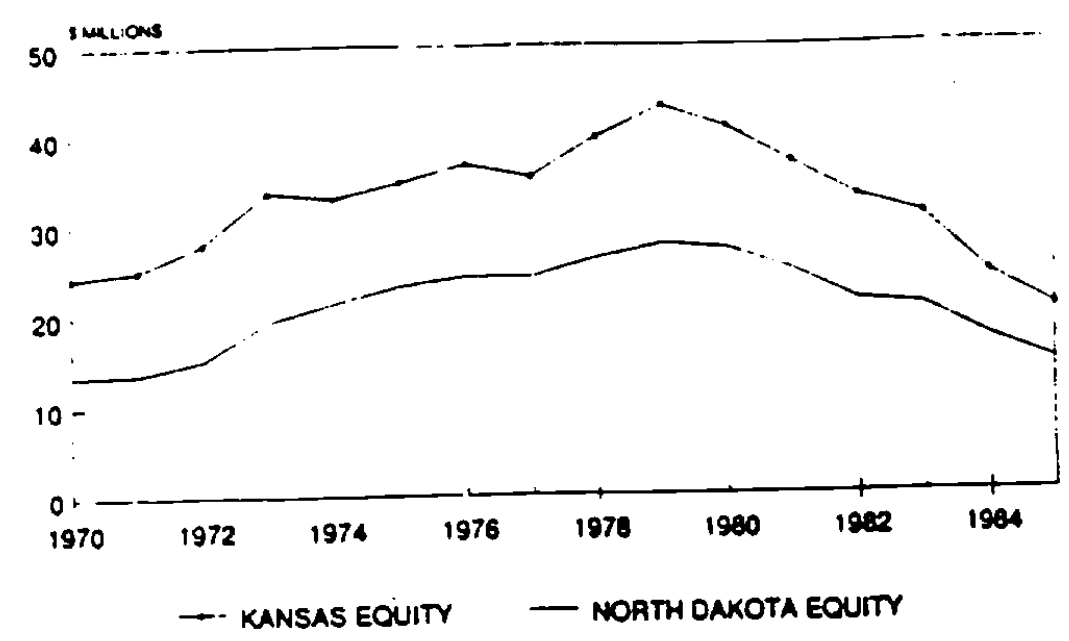

DEFUTED BY GOP DEFUTOA $(1997=100)$ 
FIGURE 5. Cropland Prices

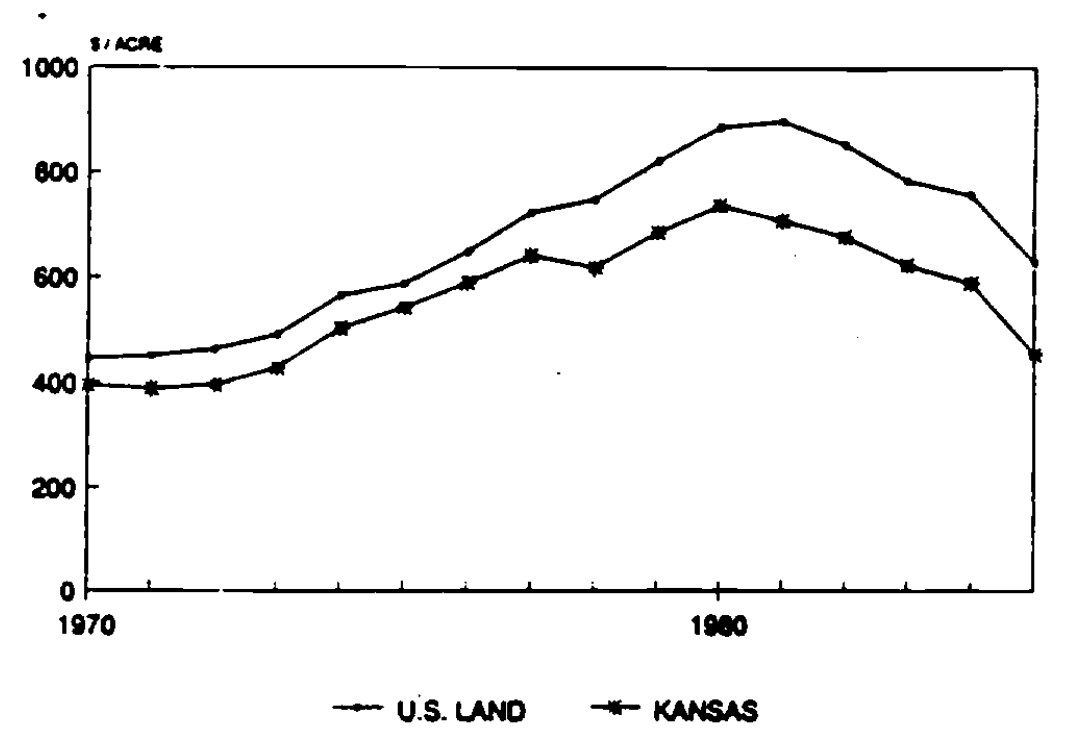

DEFUAEO OY GOP DEFLATOA (1907-100) 
to over a billion bushels in 1982 , the highest level since the early $1960 \mathrm{~s}$. In reaction, the Payment in Kind (PIK) program was introduced and idled 30 million acres of wheat base in 1983, the largest supply control effort ever. In 1984, direct payments to wheat growers rose to exceed $\$ 1.5$ billion. Yet none of these measures was capable of stemming the decline in income and equity values through 1985 .

Underlying economic situation. The supply-demand situation is sketched in figure 6. Production in 1985 is shown as the vertical line $S_{85}$. While well above mid-1970s levels, production in 1985 was only slightly higher than the 2.38 billion bushels of $1980 .^{3}$ The notable change in market conditions is on the demand side, where 2.3 billion bushels cleared the market at $\$ 3.99$ a bushel in 1980 , while 1.96 billion bushels sold for only $\$ 3.08$ (nominal) in 1985 . The demand curves sketched in show the magnitude of demand reduction that occurred, and the separate demand function shown for U.S. exports indicates reduction in demand is accounted for entirely by a decline in the foreign demand for U.S. wheat. Exports declined by 40 percent despite lower U.S. prices in 1985 than in 1980.

Several econometric investigations were undertaken in the early 1980 s to explain U.S. wheat exports, e.g. Gallagher et al. (1981), Sharples (1982), USDA (1985). Other studies have been conducted since that time, but the ones cited indicate the informational basis for policy decisions in 1985. Two factors received most of the blame for the decline in export demand: the strong dollar and the agricultural policies of the European Community (EC). Between 1980

\footnotetext{
${ }^{3}$ Although a point is plotted at the market price of $\$ 3.08$ and 2.42 billion bushels on $S_{y s}$, this is not a point on a supply curve in the usual sense. The market price is not the incentive price for production, because producers also receive deficiency payments and because producers held 18.8 million acres of wheat land idle in order to qualify for deficiency payments. The underlying market supply curves for 1985 is somewhere to the right of $S_{z s}$ for prices above $\$ 3$.
} 
FIGURE 6. Wheat Supply and Demand

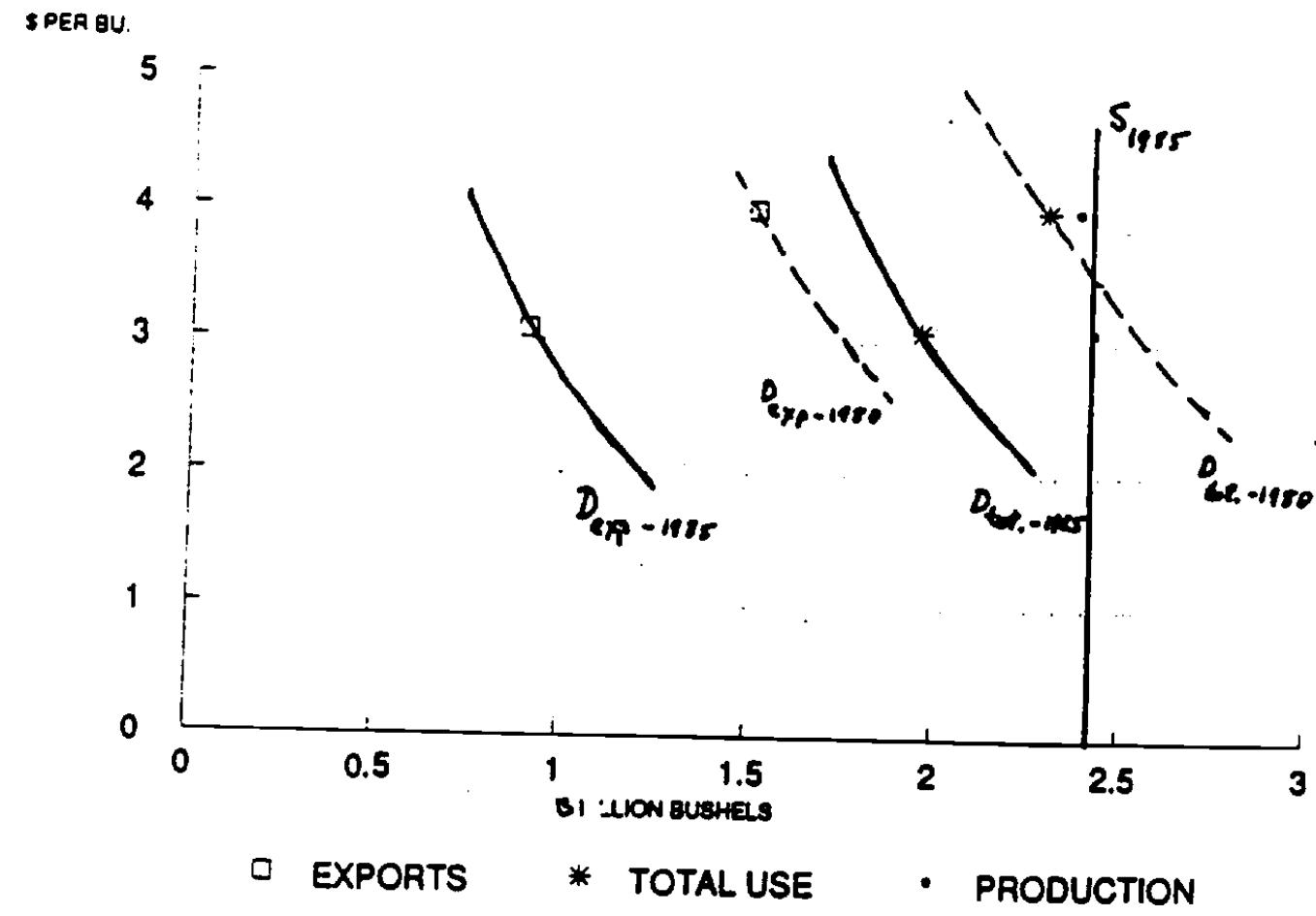

CROP YEARS: JUNE THRU MAY 
and 1985 the dollar rose 17 percent against the Canadian dollar and more than doubled against the French franc, the principal alternative sources of wheat in world trade. The overall tradeweighted value of the U.S. dollar rose about 60 percent. An exchange rate weighted by wheat export market shares rose 50 percent over this period (Dutton and Grennes). This means that the apparent fall of 25 percent in the dollar price of wheat between 1980 and 1985 was actually a rise of about that much relative to competing sellers in terms of the buyers' currencies.

EC policies in this period were a continuation of those in effect since the 1960 s under the Common Agricultural Policy(CAP) of the EC. Wheat prices received by producers in the EC have averaged about double the U.S. farm price. The main means of protection is a variable import levy, a tariff adjusted weekly to make up the difference between world prices and the protected ("threshold") price level in the EC. In 1985 the levy varied between 57 and 140 ECU's ( $\$ 64$ and $\$ 175$ ) per metric ton, 40 to 110 percent of the world (Rotterdam) average price. This mechanism provides EC farmers with a price that is not only high but also stable.

Behind this protective wall EC wheat production expanded steadily, despite a limited land area. Between 1969-71 and 1989-91 the wheat area of Western Europe (including 4.0 million hectares outside the EC in 1970 but now in) increased from 17.1 to 17.6 million hectares, a little over half the U.S. wheat area. Yield per hectare, however, increased more sharply, from 2.7 to 5.1 metric tons per hectare, a rate of growth of over 3 percent annually. Over this period U.S. wheat yields grew at a rate of about 0.5 percent annually. By 1989-91 U.S. yields were a little less than half of European yields. EC yields grew not so much through genetic improvements as through increasing and increasingly sophisticated use of chemical fertilizers and pesticides. 
EC production methods have been tried in humid areas of the U.S., and have doubled yields there, but are too costly to be profitable at U.S. wheat prices.

The result in trade is that the EC moved from self-sufficiency in wheat in 1970 to being a net exporter of about 25 percent or its production in the mid-1980s, making the EC the secondlargest wheat exporter in the world. These exports are accomplished in the face of EC internal prices well above world-trading prices by means of export subsidies. These subsidies in the mid1980 s were $\$ 80-\$ 100$ per metric ton of wheat, bringing the EC price from $\$ 230-250$ internally to a $\$ 140-160$ world level (Rotterdam basis), and costing the EC budget $\$ 1.0-\$ 1.5$ billion annually in 1980-85.

Between 1979/81 and 1984/86, EC annual wheat exports increased about 5 1/2 million metric tons. This amounts to 200 million bushels, one-third of the U.S. wheat export decline between 1980 and 1985.

Overall, it appears plausible (from the perspective of 1994 as well as that of 1985) that the combination of the high value of the dollar and EC subsidies accounted for much and quite possibly all of the decline in U.S. wheat export demand during the early 1980s. With an elasticity of foreign demand for U.S. wheat of -1.5 , a 25 percent real price increase would reduce U.S. wheat exports by about 500 million bushels. Together with the 200 million bushel EC export gain being shared proportionally by export losses of the U.S. and other wheat exporters, one can explain a decline of about 600 million bushels, which is the entire 1980-1985 actual loss.

Another factor that received much attention in 1981-85 was the role of U.S. wheat policy, particularly the high prices paid for grain entering the Farmer-Owned Reserve and acreage controls, especially the reduction of 16.5 million acres of wheat harvested that occurred in 1983 
under the Payment in Kind (PIK) program. Under this program U.S. wheat production fell by 350 million bushels in 1983, a reduction of 13 percent from 1982. This would be expected to cause a reduction in U.S. wheat exports; but at the same time Farmer-Owned Reserve stocks were reduced by 450 million bushels-the payment in kind was in the form of CCC stocks. So it is not clear that the PIK program reduced exports (or propped up world prices to the benefit of the EC). But is clear that the combination of high loan rates and supply management during 1981-85 held wheat prices (U.S. and world) above the levels to which they would otherwise have fallen. Since the 25 percent rise in the value of the dollar could have been offset by a 25 percent fall in the U.S. wheat price, it is an oversimplification to point to the value of the dollar but not U.S. price supports as a cause of the wheat export slump.

\section{Political Situation in 1980-85}

The economic problems of administering the wheat program involved not only export demand but also CCC stock accumulation as demand fell, and serious financial difficulties of farmers, stemming largely from borrowing heavily at high interest rates to buy land at the high prices of 1979-81. So it is not obvious that wheat growers would have concentrated upon the export market as the principal source of their problems, or export subsidies as a plausible remedy. Nonetheless, there was a heavy emphasis on wheat export issues by all the interested groups: farmers,agribusiness, economic analysts, the U.S. Department of Agriculture, and Congress. The main political decision points are listed in Table 3.

In 1983 the Reagan Administration, at the urging of Secretary of Agriculture John Block, after debate settled only at the Cabinet level, accepted the idea of ad hoc subsidized exports of 
Table 3. Events in the Political History of the Export Enhancement Program

I. 1983 Reagan Administration cabinet, responding to wheat grower requests to USDA, authorizes the use of CCC stocks to subsidize certain wheat exports.

2. April-May 1985

In an agreement between the Reagan Administration and Senate Agriculture Committee bipartisan leadership, the EEP is formally established and publicly announced as an ongoing in-kind export subsidy, with $\$ 2$ billion in CCC stocks to be used for this purpose.

3. October-Dec. 1985

The EEP is incorporated in the 1985 Farm Act.

4. October 1990

The EEP is reauthorized by Congress, and supplemented by a "GATT trigger" that reinforces and expands EEP in the event no GATT agreement is reached.

5. Dec. 1993 GATT agreement reached which requires reduction in EEP and in the EC's export subsidies. 
CCC-owed wheat to targeted North African markets where EC wheat was being sold with the help of their export subsidies. This was intended to serve the dual purpose of reducing excessive stock levels and smiting the EC. This venture was a substantial political success, affording an opportunity to attack the EC, please farmers, and hold off Congressional pressure for more sweeping programs. The impetus was thus established that led eventually to the full-fledged Export Enhancement Program.

In Congress, the idea of legislation to target in-kind export subsidies at the EC did not prevail when first seriously considered in 1983 . The principal reason given by opponents was the worry that such legislation would trigger a trade war in which the EC would increase their subsidies and perhaps withdraw previously negotiated concessions such as their duty-free binding on U.S. oilseed protucts and feed grain substitutes. In addition, the Secretary of Agriculture already possessed sufficient authorities for ad hoc export subsidies as needed for surplus management or strategic purposes.

Two years later, as the 1985 farm bill deliberations began, the situation was different in two respects: farm groups had refined their general support for export promotion to more concrete proposals; and U.S. wheat exports had declined still further while the EC's grew. In this situation the Administration's desire to continue ad hoc subsidization without binding legislation was no longer politically tenable.

Congressional debate. A detailed investigation of the political positions and arguments concerning the EEP is helped greatly by the focus of all parties on the $1985 \mathrm{farm}$ bill as the venue for debate. Existing legislation, governing target prices and acreage reduction programs, in the Agriculture and Food Act of 1981, expired with the 1985 crops. Because of economic 
problems of the farm sector and disatisfaction with existing programs, many sought substantial changes in the existing legislation.

Both the House and Senate Agriculture Committees conducted extensive hearings in preparation for the 1985 farm bill. The Senate committee, controlled by Republicans and chaired by Jesse Helms of North Carolina, appeared particularly interested in a fundamental review of agricultural policy (although tobecco policy was excluded). In 1983 Chairman Helms wrote to some 300 industry and academic people, asking for comments and suggestions for the 1985 legislation. A selection of the responses was published by the committee (U.S. Senate, 1984). In late 1984 and early 1985 both the House and Senate committees held hearings at various locations in the country and in Washington, D.C. at which academic experts as well as interested parties responded to requests for suggestions to revamp the commodity programs (U.S. Senate, 1985).

Two issues of program structure emerged for the grain programs (beyond the overriding general issue of the budget for these programs). The first was whether to support farmers' returns by means of further acreage controls coupled with increased market price support via CCC loan rates, or to let support levels follow market prices and support farm income through deficiency payments. The second was what steps to take to promote increased exports of U.S. commodities. Producer groups were divided on the first issue, with the National Farm Organization, the National Farmers Union, and the National Grange arguing for high loan rates and stringent production controls, and the (much larger) American Farm Bureau Federation arguing for less controls and market-oriented loan levels. The National Association of Wheat Growers (NAWG) took a middle position of marginal changes in the existing wheat program. 
The Reagan Administration, in its proposed Agricultural Adjustment Act of 1985, took the Farm Bureau position on phasing out acreage controls, but went significantly further in the market-oriented direction by calling for much lower target prices than any of the farm groups wanted. The Administration's wheat provisions were outlined on March 7, 1985, as:

Loan rates are based on 75 percent of national average prices received by farmers in the immediately preceding three years.

Target prices are based in 1986 on 100 percent of national average prices received by producers during the immediately preceding three years; this percentage would drop 5 percent each year until it reaches 75 percent for the 1991 and succeeding crops.

An acreage reduction will be required of program participants at the following levels: 15 percent -1986 crop year; 10 percent 1987; 5 percent - 1988 crop year; 1989 and thereafter, the authority for acreage reduction would be eliminated (U.S. Senate, Reauthorization, Part 1, p. 403).

The Administration largely prevailed on loan rates (where they took essentially the Farm Bureau position), but lost on target prices and on phasing out acreage controls. The implied target price cuts led members of the Congressional committees to label the Administration's bill "dead on arrival."

With respect to export promotion, the Administration wanted to maintain discretionary authority to negotiate with trading partners to remove barriers to U.S. exports, and to continue export credit programs and food aid programs. But there were no explicit export subsidies 
proposed. In Congress and among agricultural interest groups, however, sentiments were quite different. The successful use of CCC stocks to pay farmers for idling additional land in the 1983 Payment in Kind (PIK) program prompted several commodity groups to adopt the label for an "export PIK" program in which CCC stocks would be used to subsidize exports. The domestic PIK resulted in additional wheat on the market in the United States, partly offsetting the price-increasing effect of acreage idling. An export PIK, it was argued, would remove commodities that were overhanging the U.S. market and hence drive up U.S. prices. In February 1983, the National Association of Wheat Growers (NAWG) and the Nebraska Wheat Strike Force had testified before the Senate Agriculture Committee in favor of this general approach. Unlike the case of acreage controls the American Farm Bureau also supported the Export PIK idea, providing a united front among farm groups. ${ }^{4}$

In 1985, the wheat growers, principally through NAWG and U.S. Wheat Associates, the growers' market development arm, had been arriving at their position through many months of meetings. The wheat growers' focus on international marketing traditionally had to deal with a "prairie populist" isolationist impulse that emphasized supply management and higher prices in the domestic market. These sentiments had been fatally discredited for a majority of wheat growers by the prosperity brought by the export boom and sales to the Soviets in the 1970s. The populist impulse for an anti-government position was satisfied by the wheat growers' vociferous objection to controls on export sales to Eastern Europe and the Soviet Union in 1974-76 and 1980.

${ }^{4}$ Statements of Ron Delano, President, American Farm Bureau, Don Leslie, President, National Association of Wheat Growers, and Frank Johannsen, Nebraska Wheat Strike Force (U.S. Senate, 1983, pp. 28, 40-44). 
As the 1985 farm bill debate began, NAWG backed a "marketing loan" approach, under which producers could repay their CCC loans at the local market price of wheat and reclaim the wheat for sale. This essentially would establish a general (domestic and export) subsidy. However, the wheat growers also supported the EEP in written testimony for the Senate Agriculture Committee in 1984 (Schwensen 1984). The EEP approach was easy to assimilate to export promotion proposals NAWG already had made.

On the agribusiness side, the grain exporting companies of course supported export subsidies, with caveats about maintaining the companies' autonomy in negotiating sales. Even bakers and grain millers, who might have opposed the subsidized export of their raw material, did not object. The American Bakers Association's President did not take a position on the subject, and the Millers National Association testified in favor. ${ }^{6}$ One reason is that the first major shot fired in the export subsidy dispute with the EC had been an arrangement negotiated under existing authorities of the Secretary of Agriculture in which 30 million bushels of CCC wheat was given free of charge to flour mills who then sold 1 million tons of flour (requiring about 50 million bushels of wheat) to Egypt, at a price low enough to capture that market from the EC. This "largest flour sale in history" won the hearts of the millers. A second reason is that

\footnotetext{
${ }^{5}$ Among many interesting arguments of the wheat growers, one was that the Reagan Administration "has a double standard bordering on hypocrisy. They advocate but close off export markets by placing protectionist measures against steel, textiles, and other products need to send to us to gain foreign exchange." U.S. Senate, Examining, 1985, p. 42). This is one of the very few instances in the thousands of pages of testimony on the $1985 \mathrm{farm}$ bill in which farmers rehearsed elements of their traditional free-trade line. Nonetheless, the wheat growers practical thrust was for export (and domestic) subsidies.

${ }^{6}$ Statement of Roy M. Henwood, President, Millers National Association, U.S. Senate, 1983, pp. 257-59; Statement of Robert Wager, President, American Bakers Association, U.S. House, "General Farm Bill," Part 5, pp. 82-84.
} 
subsidies paid in kind out of existing stocks would place additional wheat on the market and would not raise the domestic price of wheat as a cash export subsidy would.

Executive Branch Action. Senator Dole took the lead in organizing a series of meetings in spring, 1985, to get the Reagan Administration to establish a targeted export subsidy program focused on grains, especially wheat. Representatives of NAWG as well as other farm groups attended these meetings, in Dole's office. In May 1985, the Administration (represented by OMB, and USDA) and the Senate leadership (principally Dole and Senator Zorinsky) agreed to implement under existing authorities' an Export Enhancement Program.

In particular, the Export Enhancement Program was given the breath of life by the conjunction of interests represented by three individuals: Senator Zorinsky's strong desire, as the ranking Democrat on the Agriculture committee and representative of Nebraska, for a substantial export subsidy program; David Stockman's need for Democratic votes on key economic legislation; and Senator Dole's brokering savvy, with interests in supporting both the Administration (as Majority leader) and Kansas wheat growers. Stockman agreed the Administration would implement an export subsidy program, in exchange for Zorinsky's vote on the budget resolution containing the Reagan Administration's fiscal proposals, with the subsidies to take the form of unwanted CCC surplus commodities with a zero budget score.

The agreed-upon program committed $\$ 2$ billion worth of CCC-owned commodities to be made available as a bonus to U.S. exporters to expand sales of U.S. agricultural commodities in

\footnotetext{
'Authorities of the Secretary of Agriculture as Chief Executive Officer of the Commodity Credit Corporation under the CCC Charter Act of 1936.
} 
targeted markets. The objectives stated were to increase U.S. farm exports and to encourage trading partners to begin serious negotiations on agricultural trade problems.

Guidelines for the EEP, established by the Economic Policy Council of the White House, were that each subsidized sale should meet the following criteria: (1) additionality, i.e., net increase in export sales caused by the subsidized sale; (2) targeting to displace competing exporters who are subsidizing their sales; (3) a net gain to the U.S. economy; and (4) budget neutrality. Each proposed EEP initiative was to be tested against these criteria by an interdepartmental committee chaired by the U.S. Trade Representative and USDA, but also having representatives of OMB, CEA, Treasury, State, Labor, Commerce, and NSC. It was never publicly stated how the "net gain to the U.S. economy" and "budget neutrality" criteria were to be defined and measured. Participants in the process indicated that criterion (3) was not a factor in interagency debate, although (1), (2) and (4) were.

Despite the creation of the EEP through Executive Branch action, farm and commodity groups were so strongly in favor of an export subsidy program that Congress wished to exercise authority and claim authorship of the Export Enhancement Program by establishing it in the 1985 farm legislation. The key general issue ${ }^{10}$ was whether to target export subsidies to counter competitors' subsidies or to subsidize exports more broadly. The House Agriculture Committee

\footnotetext{
${ }^{8}$ Recall that the EEP was annoilnced in the months leading up to the Ponte del Este meeting which launched the Uruguay Round of GATT negotiations.

${ }^{9}$ In November, 1989, USDA published revised guidelines in the Eederal_Register which emphasized the trade policy objectives of challenging competitors who subsidize exports and encouraging negotiations in the Uruguay Round. See Ackerman and Smith, 1990, pp. 6-7.

10 "General" meaning basic principles of design. Committee deliberations devoted more time to specific issues of interest to members (e.g., how much white wheat from Washington in the program) than to any general issue.
} 
took the broad view that subsidies in kind would boost exports by "countering the effects of foreign subsidies in international markets; compensating for the high value of the dollar; alleviating the cost of transportation" of U.S. agricultural goods "(U.S. House of Representatives, Repurn, 1985, p. 71). This led the House to support a broad, untargeted export subsidy program called BICEP - Bonus Incentive Commodity Export Program - apparently to highlight the application of governmental muscle to agricultural exports.

Legislative Action. The Food Security Act (FSA) as finally enacted in December 1985 reflected the Senate's closer ties to the Administration by codifying the EEP essentially as the Administration had established it six months earlier. The main issues, as often in enabling legislation, were what the Executive Branch "shall" (be required to) do and "may" (has discretionary authority to) do. The 1985 Act required the Secretary of Agriculture to provide CCC commodities at no cost to "United States exporters, users, and processors and foreign purchasers," and required that a total of $\$ 2$ billion in CCC commodities be used for this purpose during the three fiscal years ending September 30, 1988. The purposes which the subsidized exports were to serve are even more broadly stated than in the House bill: in addition to combating other countries' subsidies and the high value of the dollar, export subsidies may be used to offset "the adverse effects of U.S. agricultural price support levels that are temporarily above the export prices offered by overseas competitors in export markets" (U.S. Code 99 STAT 1483).

\footnotetext{
"Transportation costs are a quantitatively small but highly politically charged issue in U.S. export promotion programs. "Cargo preference," a requirement that food aid be shipped on U.S. vessels, has been an issue in EEP, export credit, and sales to the Soviets. Cargo preference has not been required for EEP shipments.
} 
In addition, the Act authorized the unlimited use of cross-subsidization, i.e., the use of one CCC commodity to subsidize the export of another. This was politically important because many commodity interests, including processed products and products which did not have price support programs, prevailed upon the Agriculture Committees for support. Egg producers and pork producers, for example, testified that they needed assistance in competing with EC export subsidies. But no CCC stocks of these commodities existed. The legislation shared EEP benefits across commodities by permitting CCC wheat stocks to be used to subsidize egg or pork EEP exports, for example..$^{12}$

The 1985 Act thus established the authority for either narrowly targeted or broad-based export subsidies, and mandated $\$ 2$ billion in spending on the program over three years. ${ }^{13}$ The EEP was not subject to discipline in the annual appropriations process, because the Appropriations Committees provide generally open-ended funding for the Commodity Credit Corporation to achieve its price support mandates. The Committees do not control how the CCC uses its acquired commodity stocks. Congress could have brought budgetary disciplines to bear

\footnotetext{
${ }^{12}$ The EEP is not as barter-based as this discussion might suggest. Exporters never received actual tons of CCC grain as a subsidy, but rather certificates entitling them to grain at any time up to an expiration date six months from the date of issue. A market quickly emerged in which these certificates could be sold at only a small discount from the market value of the grain. Since exporters could take their transactions costs into account in their bids, the subsidy in kind is very close to the equivalent of a cash subsidy. And when available CCC stocks ran out in 1991, the program was smoothly converted to one where certificates are redeemable for cash.

${ }^{13}$ In the context of budgetary pressures, authorized spending for this period (FY 1985-88) was amended to a reduced minimum of $\$ 1$ billion and a maximum of $\$ 1.5$ billion in 1986 . However, the actual value of bonuses for this 3-year period turned out to be $\$ 2.2$ billion. After the $\$ 1.5$ billion ceiling was reached, in mid 1987, USDA announced that EEP bonuses would continue under the CCC Charter Act under which the EEP was originally established (see Ackerman and Smith, p. 5, for more detail on authorization and spending under EEP).
} 
by scoring EEP costs in Budget Committee proceedings. However, the Congress agreed with OMB on zero scoring for EEP. The principal argument was that $\mathrm{CCC}$ commodities cost so much to store that it was worth about as much to give them away as to keep them. In addition, to the extent that increased exports increased the U.S. market price, deficiency payments for wheat and other target-price commodities would be reduced.

The EEP in a Broader Political Context. The Export Enhancement Program came into being with very little opposition between February and December 1985. Why was the way so clear? The natural opponents of an export subsidy are U.S. domestic wheat buyers and foreign wheat producers. In the case of EEP U.S. millers were diverted by their participation in subsidized flour exports and by the release of CCC stocks to pay the subsidies, as discussed earlier. The bakers and broader consumer groups were relatively weak participants, and their participation in the 1985 farm bill debate was focused on opposition to acreage controls and on limiting budgetary outlays. The latter point was the dominant item of contention throughout 1985.

The 1985 farm bill was debated in the culminating period of the "farm crisis" and at the same time the bill known as Gramm-Rudman-Hollings ${ }^{14}$ was being developed. Just before the Congressional farm bill debate began, in February 1985, President Reagan vetoed a farm bailout bill that would have forgiven billions of dollars of farm debt and made new subsidized and guaranteed loans to farmers in trouble. The Administration's proposal, in its Agricultural Adjustment Act of 1985 , to go still further and cut benefits that farmers were already receiving

\footnotetext{
${ }^{14}$ Enacted as the Balanced Budget and Emergency Deficit Control Act of 1985, to become effective in early 1986.
} 
caused this aspect of the bill to be labelled, correctly, as "dead on arrival" by Congressional Democrats.

While the testimony on export promotion was proceeding as described earlier, much more contentious and widely reported hearings were being held on the broad problems of agriculture. Newsweek had a 5-page story featuring an Iowa State agricultural economist's estimate that 12 percent of U.S. farmers would go out of business in 1985, and 30 percent were "sliding toward insolvency" (Newsweek, Feb. 18, 1985, p. 52). At a special hearing staged by Congressional Democrats (no Republicans attended) three famous actresses of the day (Jane Fonda, Jessica Lange, Cissy Spacek) appeared, each of whom had starred in movies featuring heroic struggles of farmers against economic adversity and insensitive bureaucrats. The actresses "decried the farm policies of the Reagan Administration as uncaring and insensitive to rural America's anguish" (Washington Post, May 7, 1985). ${ }^{\text {is }}$

In this context it was probably not reasonable to expect national consumer groups to adopt positions in support of cuts in farm support, and none did.

The role of outside experts on the economics of agriculture is more difficult to explain. Many such experts submitted testimony, on many aspects of farm programs. In 1984, twelve economists made written contributions to the Senate Agriculture Committee's trade policy compendium (U.S. Senate, 1984b). Of these, none proposed export subsidies, and the three that

\footnotetext{
${ }^{15}$ This was the only 1985 agricultural hearing to run on all 3 prime time network newscasts. The Post quoted one actress as saying "the solid core of our agriculture is threatened," and further quoted: "It is heartbreaking to witness their anguish as they watch their lives being stripped away, Lange said of farmers as she choked back tears." The Post played the story on page 1, but it was page 1 of the "Style" section under the headline, "The Farm Act." This deflated the impact somewhat.
} 
addressed the issue directly all raised objections to the idea (D.G. Johnson, D.A. O'Rourke, and J.A. Sharples). In the 1985 hearitigs, also, no economists supported the EEP. This may be in part due to a lack of opportunity, since the EEP was not spelled out in a form that testifying economists could react to before it was introduced as a non-legislated fait accompli in May 1985. But even if economists did not object formally to the EEP, it was clear from their general comments on trade pulicy that they would have opposed it because of concern about igniting a subsidy war and because of low expected benefits to farmers per dollar of cost to consumers and taxpayers.

Another silurce of independent testimony was the statements of five former Secretaries of Agriculture - Orville Freeman (Kennedy), Clifford Hardin (Nixon), Earl Butz (Nixon/Ford). John Knebel (Ford), and Bob Bergland (Carter) — in U.S. Senate (1984b). Their comments focused on trade issues, and supported various measures to stimulate exports. But none advocated direct export subsidies.

During Octuber-December, 1985 the farm bill assumed its final form. The House passed its version un Octuber 8 , the Senate on November 22, and the Conference Committee reached agreement un a bill which achieved final passage on December 18. This period was marked by sharp debate. The anti-farm support side was almost entirely a matter of budgetary exposure, the end-game issue turning on whether target prices should be frozen for I year (Administration) or 4 years (Congressional Democrats) before declining. The ultimate compromise was a two-year freeze followed by modest cuts. The wheat target price $\$ 4.38$ per bushel for 1985 crops, was 
kept at $\$ 4.38$ in 1986 and 1987 , then cut in steps to $\$ 4.00$ by $1990 .^{16}$ Because the debate focused almost exclusively on budgetary issues, for wheat and other commodities (notably dairy), the EEP received little legislative attention.

The overall compromise achieved was of the highly pragmatic type in which legislators like Congressman Foley and Senator Dole worked from a middle ground outward to obtain a majority. Both the most ardent pro-farmer voices and most ardent budget-cutters opposed the bill. The vote for final passage was 325-96 in the House and 55-38 in the Senate. Both the Chairman of the Senate Agriculture Committee, Jesse Helms (N.C.) and the ranking Democrat, Ed Zorinsky (Neb.) voted against the bill, for opposite reasons. President Reagan signed the bill into law on Dec. 23, 1985.

In summary, the Export Enhancement Program was enacted in 1985 because wheat growers and exporters asked for it, and no interest group opposed it, except economists in general terms. Because the pressure to assist agriculture was strong, and was countered only by budgetary pressures, the OMB finding that the EEP would be budget neutral ensured its supporters of an easy political victory. ${ }^{17}$

\footnotetext{
${ }^{16}$ While there were no immediate budgetary savings through, target price cuts, it was known by the time of Conference Committee action that GRH provisions would require a reduction in deficiency payments for FY 1986 (the 1st crop year of the new bill, for which winter wheat was already planted). In the event farmers had their payments reduced by 4.3 percent in FY 1986. The wheat target price remained at $\$ 4.00$ through 1993 , and is scheduled to continue at that level through 1995.

${ }^{17}$ Congress' own budget agency, the Congressional Budget Office (CBO), has not accepted the budget neutrality argument. Indeed $\mathrm{CBO}$ has in recent years called attention to the EEP as a potential area for budgetary savings, estimating most recently a \$4.2 billion saving in FY 199599 if the baseline EEP spending of $\$ 5.0$ billion over this period were eliminated (U.S. Congress, 1994, p. 218). Their clinching argument against the budget neutrality of EEP is the following: Whatever price effects could be achieved by EEP could also be achieved at lower budget cost
} 


\section{Related Export Assistance}

In addition to the Export Enhancement Program, wheat exports continue to be promoted by:

- fond assistance, through Public Law 480 and related programs, under which about 3 million tons of wheat are shipped each year under generous credit terms that amount on average to a substantial subsidy on limited quantities in country-to-country agreements.

- export credit, with guaranteed repayment to lenders by the U.S. Treasury if the foreign borrower defaults. The interest rate is a commercial rate negotiated by borrower and lender, typically just above the LIBOR (London Interbank offer rate), a rate available only because of the guarantee. The U.S. government has had to absorb substantial losses from loans to Iray, and the possibility of big losses on credits to Russia.

- The Targeted Export Assistance program, introduced in the 1985 Act, provides matching funds for private-sector initiatives to promote agricultural exports. This program was reformulated as the Market Promotion Program in the 1990 Farm Act, and its budget has been reduced from over $\$ 300$ million authorized in 1985 to about $\$ 100$ million for FY 1994. About 10 percent of the program's expenditures have been used to promote grains and grain products with $\$ 50$ million spent in $1986-89$ (Ackerman and Smith, p. 39).

Farm and agribusiness groups have consistently supported these programs. Groups interested in international development - mainly nonprofit foundations, and charitable organizations - have questioned the negative impact of food aid on food production in the

using acreage reductions (ARPS). With both EEP and ARPs the subject of annual policy determination, one should not hold the ARP constant when evaluating the EEP. 
recipient countries. But these groups have also supported food aid in times of famine or emergency. Other international interests have promoted food assistance for geopolitical reasons, notably to Russia, Egypt, and Pakistan. There has been no sustained political opposition to these programs, except as part of generic budget cutting.

An illustration of how these programs work in tandem is afforded by recent wheat sales to the former Soviet Union. In FY 1992, roughly coinciding with President Yeltsen's first year as leader of Russia, the United States exported 8.7 million metric tons of wheat to the former Soviet Union. Market receipts for the wheat were $\$ 1.022$ billion, or $\$ 117$ per ton. Russia and the other former republics could not afford to pay hard currency for this wheat. The wheat was sold through a combination of government-guaranteed commercial credit, EEP subsidies, and food aid programs. $\$ 810$ million in credit was allocated to the FSU for wheat and wheat product purchases in late 1991. $\$ 350$ million in EEP bonuses were paid on 8.4 million tons of wheat in FY1992 (\$41.50 per ton on average). The credit program, called GSM-102, involves short-term credit, up to three years, with a repayment schedule beginning in the first year. By November 1992 Russia's repayments were sufficiently in arrears to trigger their suspension from the program. However, in FY1993 a more liberal credit program for Russia was established under "Food for Progress" authorities of USDA. This credit is financed directly from the U.S. government rather than through commercial banks, and has a longer repayment period and lower than commercial interest rates. Credit is even granted, using CCC funds, for freight and handling costs. In addition, 700,000 tons of feed wheat have been donated to the FSU. (For further details, see USDA, 1993, pp. 39-45). Overall, while the EEP subsidy on U.S. wheat exports to 
the FSU amounts to about 30 percent of the U.S. Gulf price, the package altogether amounts to a much larger export subsidy.

The main political pressures in these subsidies have come from Representatives and Senators whose wheat growers have been concerned that credit has not been allocated quickly enough to keep wheat moving. Fiscal cautions have also been raised, and have probably restrained FY 1993 and 1994 wheat sales to the FSU somewhat.

\section{Consequences and Evaluation of the Program}

Questions were being raised about the effectiveness of Export Enhancement Program even before its legislative enactment. The Administration announced its first EEP initiatives in May, 1985. By October only two sales had been made, 500,000 tons of wheat and 175,000 tons of wheat flour to Egypt. The administration in May had appointed an Advisory Committee on the Export Enhancement Program, consisting primarily of commodity group and agribusiness representatives. In August, the Committee's representatives from the National Corn Growers and U.S. Wheat Associates, joined by four other committee members, issued a press release saying they were "disappointed and frustrated over the lack of any concrete results from the EEP" (National Corn Growers, 1985). In October and November the House Committee on Agriculture's Subcommittee on Department Operations, Research, and Foreign Agriculture held hearings to review complaints about EEP administration.

The substance of the commodity group complaints was that the EEP was being carried out in too restrictive a manner. In particular, the groups argued that wheat sales to the Soviets fell under the EEP criteria listed earlier. The EC had since 1980 expanded its subsidized wheat 
exports to the Soviet Union substantially, yet USDA had not approved an EEP initiative for U.S. wheat sales to the Soviet Union. The Soviets were switching wheat purchases from the United States to the EC, even though that meant not honoring their purchase agreements with the U.S. under a previously negotiated long-term grain sales agreement. The Hearings made clear, however, that even if USDA were willing to accede to the Soviets' ploy to acquire previously agreed upon shipments at a lower price, potential exporters of non-agricultural products to the USSR would not accept subsidizing wheat sales to the USSR while other holds on US/Soviet economic arrangements were in place as part of the political struggle for freer emigration from the USSR (U.S. House, 1986). It was not clear, however, which particular export industries Congress was hearing from on this point.

Apart from being subject to such political constraints, the procedures for implementing EEP were far from clear. There were (and are) two main steps: Administration approval of an EEP initiative, and USDA's acceptance of exporters' bids for bonuses under the initiative. Approval of an initiative is done by the EEP interagency committee described earlier, after a proposal by USDA, based on the criteria of additionality, targeting, cost effectiveness, and budget neutrality. ${ }^{18}$ For example, one of the first initiatives approved was for the sale of 1 million tons of wheat to Algeria. With the initiative in place, a U.S. exporting firm can attempt to arrange a sale with an importing firm (or government agency) in Algeria. If the exporting firm cannot meet the price offered by competing exporters, in this case the EC, it will apply to USDA for a "bonus", of commodity certificates equal in value to the amount needed to make up the difference

\footnotetext{
${ }^{18}$ The outside EEP Advisory Committee understood there to be two additional criteria: coincidence with overall U.S. trade policy, and approval by the interagency committee (U.S. House, Review, 1985, p. 88).
} 
between the cost of U.S. wheat delivered to Algeria and the price negotiated to make the sale. USDA assesses U.S., EC, and Algerian market conditions and either approves or disapproves the deal. If the transaction is approved, the firm receives the certificate requested and ships the wheat.

This mechanism is quite different from the approach used for wheat export subsidies by the EC, or by the United States in its pre- 1972 program, of periodically announcing a dollar value of the subsidy, say $\$ 35$ per ton, and then letting any firms who export U.S. wheat collect that amount on the exported quantities. The approach raises questions of how USDA can determine, for each proposed sale, what the competitors' price is. Wouldn't the competitors' price itself be affected by EEP? And, is there sufficient incentive for U.S. commercial exporters to obtain the highest possible market price?

USDA Undersecretary Amstutz testified on the new EEP mechanism as follows:

Program implementation, in terms of mechanics such as tendering and contractual arrangements, has remained flexible. Procedures have varied from country to country to accommodate the individual buying systems of the importing nations involved in the program.

The bonus is to be sufficient to allow our commodities to be competitive, but it is not intended to undercut the world market price. In other words, the program is designed to er.sure that sales made under it are ar commercial, not concessional, prices.

To ensure that we are meeting these competitive and commercial objectives, a price review process has been developed. The process calls for a review of the level of both the bonus and the sale price. This is to assure not only that the bonus paid to exporters is not too high, but also that the sale price, relative to subsidized foreign competition, is not too low.

In the price review we determine the cost of delivering the U.S. commodity to the foreign buyer and the price at which the same commodity can be delivered to the same destination by subsidized foreign competitors. 
The difference between the two - the amount by which the competition can under-price us - is used in determining the acceptable bonus.

Currently, an exporter is required to post a performance security with CCC before CCC will consider the exporter's offer. Once an offer is accepted, the exporter reserves bonus commodities from CCC inventories. After shipment, the exporter must furnish proof of export to request delivery of the bonus commodity. After the exported goods arrive in the destination country, USDA releases the performance security posted by the exporters. (Amstutz, p. 142).

Neither this nor other statements of USDA have answered questions about U.S. exporters' incentives and pricing behavior under the EEP. But these were not issues of concern to Congress in 1985 (or later). The main objection of House Agriculture committee members to the EEP was their desire for a program that would subsidize most or all wheat exports, not just a subset of targeted markets. Two main concerns were raised about the operation of the EEP: first, it would antagonize traditional buyers of U.S. commodities who did not receive the subsidized price, hence possibly driving them to other suppliers; and second, it would drive down the prices received by nonsubsidizing competitors like Argentina and Australia. At the House hearings, several commodity groups raised the first concern, and the General Accounting Office the second.

\section{Economic Analysis of EEP}

While economists' analyses did not play a role in the 1985 legislative process, analytical work was available which did not make the EEP attractive. The standard argument (e.g., in Dixit and Norman) that for purposes of domestic income redistribution a domestic distortion is always preferable to a border distortion, should apply to agricultural export subsidies undertaken for the purpose of farm income support. The question addressed in agricultural economists' analyses is whether there are second-best or other special characteristics of the world wheat situation that make targeted, in-kind export subsidies more attractive. 
General (Untargeted) Export Subsidy. Consider the effect of a subsidy in the 1985 U.S. wheat market. Using the elasticities of Paarlberg (1984) of -1.5 for the short-run demand for U.S. wheat exports and -0.2 for U.S. domestic demand, the 1985-crop situation is shown in figure 7. Of the 2,400 million bushels produced, 900 million bushels were exported and 1,050 were consumed domestically, leaving 450 million bushels added to CCC stocks at the farm-level supported price of $\$ 3.10^{19}$ Despite the inelastic demand for domestic use, CCC activity creates perfectly elastic demand at the market support price (not the target price).

Suppose we introduce an export subsidy, $s$, of $\$ .40$ per bushel ( $\$ 15$ per ton). This drives down the world price of wheat by $\$ 15$ per ton and increases the demand for U.S. wheat by about 300 million bushels. The U.S. domestic price remains unchanged, because of the CCC loan program. If the price were to rise above the supported level, wheat would not go into the CCC program; but there is too much wheat to clear the market at any price above the support level. CCC loan availability creates a perfectly elastic demand at the support price level, so the total demand for wheat, in the absence of the export subsidy, is $D_{\mathrm{T}}$. Introducing the export subsidy shifts total demand to $D_{\mathrm{T}}^{\prime}$. Wheat is exported rather than going into stocks.

The gains and losses to the United States are as follows. Domestic consumers and producers are unaffected, since the U.S. price remains the same. Budgetary outlays are $s$ times the quantity exported, here $\$ .40 \times 1.2$ billion bushel $=\$ 480$ million annually. But there is a

\footnotetext{
${ }^{19}$ The legislated support price was $\$ 3.30$, but this translated to an average farm-level price of $\$ 3.10$ in the $1985 / 1986$ marketing year.
} 
FIGURE 7. Wheat Export Subsidy

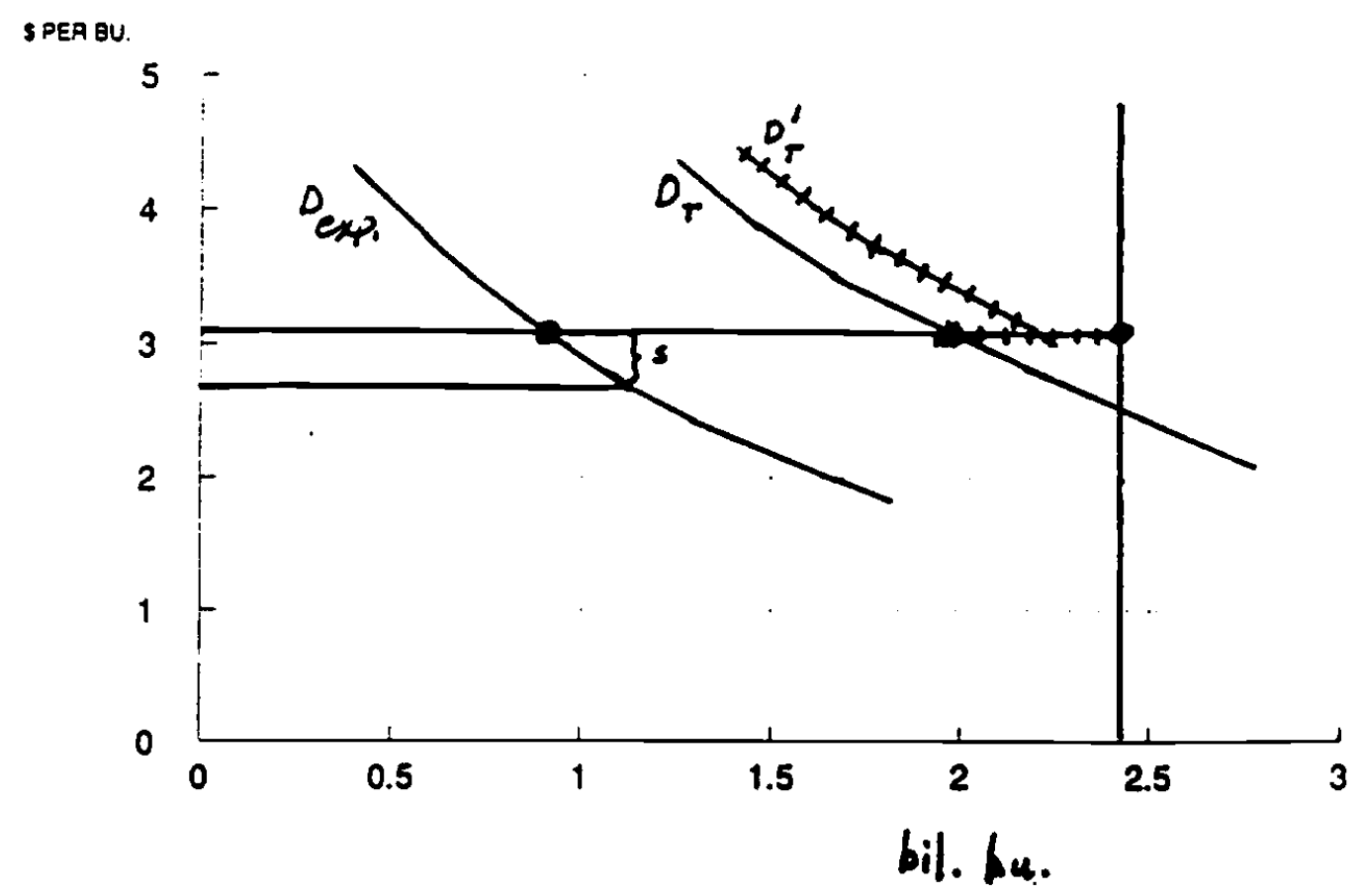


budgetary saving from not having to pay CCC loans of $\$ 3.10 \times 300$ million bushels, or $\$ 930$ million. This implies a net budgetary saving of $\$ 450$ million in the current fiscal year. However, current-year flow accounting (although it is what drives budget scoring) does not take into account the value of the wheat the government owns. There is no agreed-upon valuation of CCC stocks, or even an agreed-upon method for determining their value. The principal necessary calculations are (discounted) expected storage costs over the period the grain will be held, and the expected value of the grain when sold. Assuming 3 years of storage costs and eventual sale at roughly the loan rate (acquisition price), the present value of $\$ 930$ million spent on CCC wheat is about half its cost, or $\$ 465$ million. So the net government savings are $(480-465=$ ) $\$ 15$ million.

According to the analysis so far, farmers do not gain from the export subsidy. However, this also occurs only because the diagram shows only the current year, in which wheat acreage and input decisions are fixed by wheat program provisions. Under the wheat program the supply function is changed in more complicated ways than is the demand side of the market. Producers receive a deficiency payment that they know will make up the difference between the target price ( $\$ 4.38$ in 1985) and the U.S. average price in the 5-month peak marketing season (June-October). So they should make planting decisions, in the preceding autumn for winter wheat and spring for spring wheat, based on the target price, not the expected market price. However, in order to qualify for deficiency payments farmers had to stay within their acreage base, and hold idle 20 percent of base acreage. Therefore, the incentive price for growing wheat is considerably less than the target price. For 1985 I have estimated the average producer's incentive price was about $\$ 3.75$ per bushel as compared to the $\$ 4.38$ target price (Gardner 1991). Moreover, producers are 
limited in their ability to respond to the incentive price. They cannot expand acreage as already mentioned. They can expand output by using more fertilizer or other inputs, but deficiency payments provide no incentive for this because payments are made on a fixed (since 1981) yield base which is assigned to each producer. A final complication is that, principally because of land idling requirements, some farmers choose not to participate. For them the incentive price is the market price.

In calculating farmers' gains from an export subsidy, these considerations come into play through the annual determination of the acreage reduction percentage (ARP). The reason the ARP was as high as 20 percent in 1985 (and 27.5 percent in 1986 and 1987) is the large prior CCC stock accumulation. The 450 million bushels added to stocks from the 1985 crop was piled on top of the 1.4 billion already accumulated. If 300 million bushels could have been exported instead of being added to stocks, the ARP could have been reduced accordingly. At the U.S. average yield of about 35 bushels per acre, 8 1/2 million acres could have been planted that had been held idle. At a net rental value of wheat land of $\$ 40$ per acre, the gain to wheat producers would be $\$ 340$ million.

The results of the two ways of accommodating a general wheat export subsidy under 1985 conditions are summarized in Table 4.

Given the existence of excessive CCC wheat stocks or ARPs, an export subsidy program has quite small costs. However, an option with smaller costs would result from a domestic consump- tion subsidy. In figure 7, if s were paid on all consumption the budget cost of the subsidy would 
Table 4. Results of alternative implementations of a wheat export subsidy under mid-1980s market conditions.

policy 1:

$\$ .40$ export subsidy holding ARP constant and reducing $\mathrm{CCC}$ stckks by 300 mil. bu. policy 2:

$\$ .40$ export subsidy holding CCC stocks constant and reducing ARP by $81 / 2 \mathrm{mil}$. acres

million dollars

\begin{tabular}{lcc}
$\begin{array}{l}\text { budget } \\
\text { cost of subsidy }\end{array}$ & -480 & -480 \\
$\begin{array}{l}\text { budget savings } \\
\text { on CCC stocks }\end{array}$ & -465 & 0 \\
\hline $\begin{array}{l}\text { overall budget } \\
\text { effect }\end{array}$ & -15 & -480 \\
farm income & 0 & 340 \\
effect & 15 & -140
\end{tabular}


be offset, except for a sinall triangle, by gains to U.S. consumers. ${ }^{20}$ An alternate policy would be to pay a larger subsidy on domestic consumption than on exports (or even taxing exports). This avoids using U.S. Treasury funds to provide lower-cost consumption abroad.

Special Features of EEP. The Export Enhancement Program differs from a general export subsidy in three key respects: targeting of particular importing countries to receive subsidies: limiting the quantity of wheat eligible to each targeted country, and payment in kind of the subsidy in the form of CCC stocks.

Targeting and quantity limitation are attractive because they reduce budgetary outlays for subsidies and because they do not undercut the prices of our non-subsidizing competitors, notably Argentina and Australia. At least that is the thought. We pay the subsidy of $s$ to reduce the price of, say, one-third of U.S. wheat exports while continuing to sell the rest at unsubsidized world price.

The question with respect to country targeting is whether the policy is capable of creating the price wedge $s$ between the targeted and non-targeted wheat importing countries.

Transportation and other transactions costs between these countries suggests there would not be fully price-equalizing arbitrage. But there is also the problem of redirection of the competitors' wheat exports. If the United States sends wheat to Algeria, replacing EC wheat, then the EC

\footnotetext{
${ }^{20}$ One might consider pushing this policy further by letting the support price fall to a level that permits the entire 2.4 billion bushels produced be consumed. In figure 7, this is achieved at a price of $\$ 2.00$ per bushel. As compared to the $\$ 3.10$ price, this policy would add $\$ 1.10 \times 2.4$ billion $=\$ 2.64$ billion of budget outlays, partly offset by consumer gains of roughly $\$ 430$ million and net CCC stock savings of $\$ 700$ million (assuming CCC stocks valued at half the support price) or $\$ 510$ million in producer gains if ARPs are reduced and stock buildup maintained. In either case the net cost of the policy is over $\$ 1.5$ billion (mainly because of the bonanza given to foreign consumers). In fact, the 1985 "marketing loan" proposal of the wheat growers would have generated this kind of result. Because of its potential budget costs (which depend crucially on the elasticity of total demand for wheat) this proposal was a non-starter in the 1985 Congressional debate.
} 
sends the wheat that otherwise would have gone to Algeria to Iran, say. But despite the multichannel nature of world wheat trade there are possibilities of U.S. export subsidies changing the spatial price pattern. and some economists have developed arguments on how the United States could exploit differing elasticities of demand for U.S. wheat to profit from targeted subsidies as a form of price discrimination (Dutton 1992). However, the knowledge base on these elasticities and arbitrage possibilities is essentially nil, and these studies have no detectable connection with the actual administration of the EEP, or with what the wheat producers had in mind.

The quantity limitation raises other problems. As the wheat growers noted in their criticism of the first EEP sales to Egypt, once the sales were complete the EC reentered the market and sold at the pre-EEP prices. It appears that the price at the margin is the nonsubsidized price, so there is no reason for the EEP recipients to consume more wheat with the EEP in place than without it. But if no country consumes more wheat because of the EEP, the market-clearing price will remain unchanged, as will U.S. and other countries' exports. EC exports and prices remain unchanged, and the United States will have done nothing to force the EC to increase their export subsidies, hence driving them to the GATT bargaining table. We have simply transferred funds from U.S. taxpayers to Egyptian buyers (probably the government) on an intramarginal quantity of wheat imports. However, there are complications.

First, it is not clear that the U.S. EEP quantities are so limited as make sales intramarginal in the targeted countries. Second, payment in kind makes a real difference, even though subsidies are given to wheat exporters in the form of generic certificates that are transferable and can be used against any CCC-owned commodity. Even if exporters cash out their certificates, the buyer 
of them must redeem them for $\mathrm{CCC}$ commodities before their expiration date, so that wheat will inevitably be redeemed. ${ }^{21}$ This was important in 1985 because the CCC by law could not dispose of its stocks until market prices rose well above their current or likely attainable levels. ${ }^{22}$ Therefore, the EEP provided a way to place on the market commodities that otherwise would have been sequestered. In this way the EEP tended to place general downward pressure on world wheat prices, by increasing marketed supplies. Chambers and Paarlberg (1991) argue that this effect could have caused the EEP to generate a net loss to the United States. However, if CCCstock reductions trade off with equivalent ARP changes, the supply-increasing feature of the EEP subsidy can always be neutralized.

Assessment of EEP Operations.

It seems impossible to predict much about the consequences of EEP on the basis of a general economic analysis of it. How then are the criteria to be met for EEP sales additionality, net economic gain, and budget neutrality - to be assessed against the program's operations? Turning first to the data for 1985-1992, statistics of EEP shipments are shown in Table 5. After a slow start, EEP exports reached 26.6 million metric tons in Fiscal 1988, about half of all U.S. wheat exports. ${ }^{23}$ The average subsidy reached $\$ 38$ per ton in 1987. A price

\footnotetext{
${ }^{21}$ Indeed, by the end of 1991 all available CCC commodities had been distributed to holders of certificates or otherwise sold.

${ }^{22}$ The 1985 and 1990 Farm Acts made it easier to dispose of these stocks after 1985.

${ }^{23}$ Reporting of Fiscal Year EEP data and crop year total export data creates possible confusion. Fiscal years are October-to-September and wheat crop years are June-to-May. Fiscal years are referred to by the calendar year in which they end, and crop years by the calendar year in which they begin.
} 
Table 5. Export Enhancement Program (EEP) wheat sales and bonuses

\begin{tabular}{|c|c|c|c|c|c|}
\hline $\begin{array}{l}\text { Fiscal } \\
\text { Year }\end{array}$ & $\begin{array}{l}\text { EEP } \\
\text { Sales }\end{array}$ & $\begin{array}{c}\text { Total EEP } \\
\text { bonus }\end{array}$ & $\begin{array}{l}\text { Average } \\
\text { EEP bonus }\end{array}$ & $\begin{array}{c}\text { Total U.S. } \\
\text { Exports' }\end{array}$ & $\begin{array}{c}\text { EEP } \\
\text { Share }^{2}\end{array}$ \\
\hline & $\begin{array}{l}\text { metric tons } \\
\text { (millions) }\end{array}$ & $\begin{array}{c}\text { dollars } \\
\text { (millions) }\end{array}$ & S/mt & $\begin{array}{l}\text { metric tons } \\
\text { (millions) }\end{array}$ & (\%) \\
\hline 1985 & .5 & 11 & 21.84 & 28.0 & 2 \\
\hline 1986 & 4.8 & 126 & 26.20 & 20.7 & 23 \\
\hline 1987 & 14.1 & 541 & 38.33 & 28.1 & 50 \\
\hline 1988 & 26.6 & 819 & 30.83 & 40.6 & 66 \\
\hline 1989 & 16.0 & 288 & 18.05 & 37.6 & 43 \\
\hline 1990 & 14.3 & 241 & 16.84 & 33.2 & 43 \\
\hline 1991 & 17.7 & 767 & 43.18 & 26.7 & 67 \\
\hline 1992 & 19.7 & 813 & 41.14 & 34.3 & 58 \\
\hline 1993 & 21.6 & 1281 & 33.82 & & \\
\hline
\end{tabular}

Source: Economic Research Service, USDA

'Fiscal year exports, which differ from crop-year data used elsewhere in this paper. Constructed from USDA monthly export statistics.

${ }^{2}$ EEP tonnage as percentage of total export tonnage. 
wedge this large on substantial quantities would be expected to make a noticeable difference in world trade flows and prices.

"Additionality". As an initial step in assessing the effectiveness of targeted export subsidies under EEP, several economists have attempted estimates of additionality - the net increase in U.S. wheat exports caused by each ton of EEP-assisted shipments. If one simply regresses wheat exports on EEP tonnage using the data of table 5 for 1986-92, the result is the regression line shown in Figure 8a. This indicates that each ton of EEP sales generates 0.8 ton of exports, which indicates only 20 percent of the EEP sale replaces commercial exports that would have been made anyway, i.e., "additionality" is 80 percent. However, if we include the 3 years immediately preceding the EEP, thus incorporating a before-EEP and after-EEP contrast in the data, the result is as shown in Figure 8b. This indicates additionality of zero. These results indicate that a simple annual regression cannot provide a believable estimate of additionality.

The approach taken in the literature is to build a supply-demand model of the world wheat market, and simulate the effects of the EEP. To do this one has to model not only supply and demand equations in the countries involved, both the targeted markets and non-targeted ones, but also the trade linkages between them and the policy instruments that influence wheat trade. Moreover, some policy instruments abroad should be treated as endogenous, since they may respond to EEP. Brooks et al. (1990) argue that analyses that take policies other than the U.S. EEP as given miss a key element, at least as far as Canada is concerned. Canada's wheat export policy is not explicitly rule-driven; wheat is priced for export on an ad hoc basis by decisions of the Canadian Wheat Board, which has a monopoly on exports. The Board has announced it 
FIGURE 8a. EEP Sales and Wheat Exports

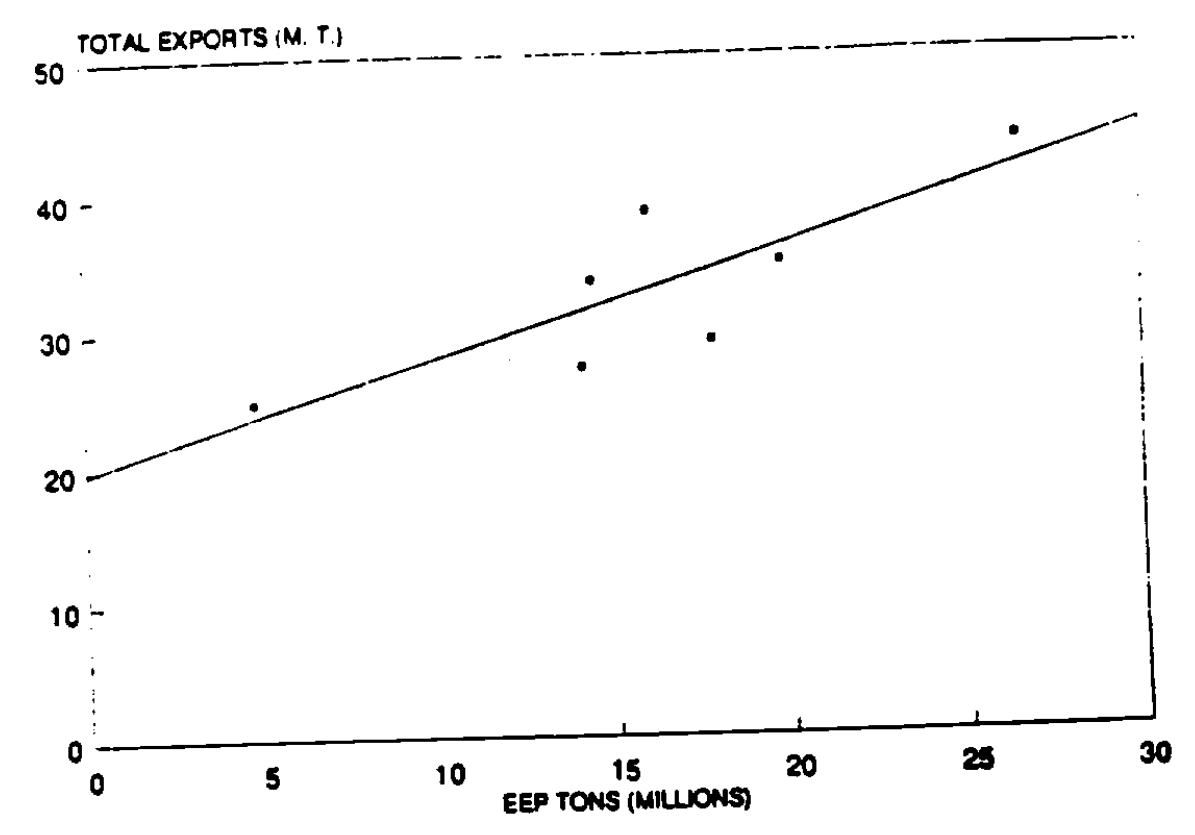

FIGURE 8b. EEP Sales and Wheat Exports

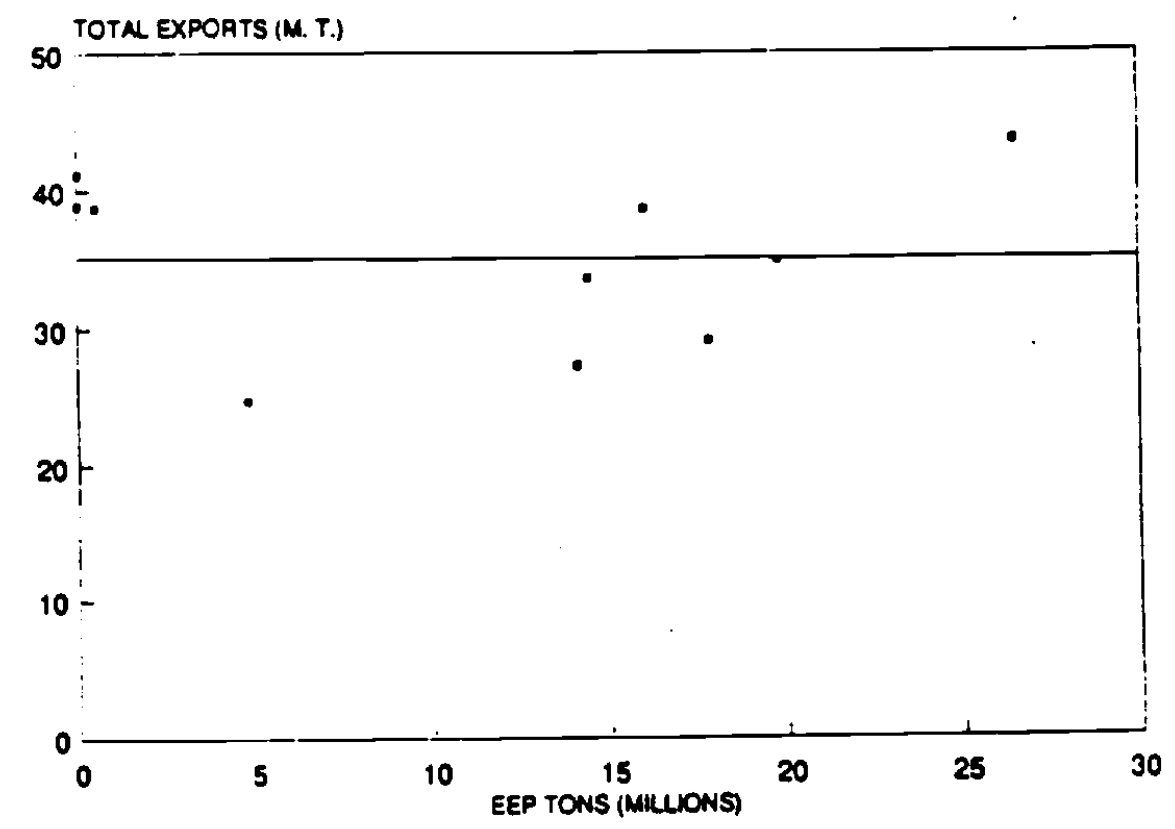

FISCAL YEARS 
has a special program to counter U.S. EEP sales, but has not revealed details, nor the prices received for Canadian wheat in the EEP-targeted markets. Australia has a similar wheat export monopoly.

Given the difficulties of specifying a simulation model that one can have confidence in for the purposes at hand, it is perhaps heartening that the range of additionality estimates is not large. Brooks, et al estimate that a ton of EEP exports added 8 to 13 percent of a ton to total exports in 1986-88. Ackerman and Smith (p. 12) summarize five USDA-ERS studies whose estimates of additionality range from 2 to 30 percent.

Additionality has become important in EEP policy because the budget neutrality of the program depends on additionality. In the earlier calculations involving a general export subsidy additionality depended only on the elasticity of foreign demand for U.S. wheat. Matters are more complicated with the targeted EEP. Until the end of Fiscal 1991, subsidies in the form of CCC stocks made budget neutrality easy to justify because of the high costs of carrying these stocks. ${ }^{24}$ Since November, 1991, when the CCC exhausted its available stocks and introduced cash subsidies, the budget neutrality of EEP depends upon the program's ability to increase the U.S. price of wheat and thus reduce deficiency payments.

The way EEP increases the U.S. price is by increasing the total demand for U.S. wheat. USDA has been using a wheat simulation model in which each million ton increase in wheat exports generates an increase of 10 cents per bushel in the U.S. farm price of wheat. The

\footnotetext{
${ }^{24} \mathrm{CCC}$ costs of holding grain are much higher than commercial storage rental rates plus the opportunity cost of funds tied up, which sum to about $\$ .40$ per bushel annually. Stocks are "rotated" (old wheat replaced with new) and relocated periodically. GAO estimates it costs the CCC over $\$ 1.00$ per bushel per year (25-30 percent of the price) to hold wheat.
} 
assumption that the CCC support level sets the market price is no longer appropriate since after 1985 the support level has been reduced and has always been substantially below the market price of wheat. Each 10 cent rise in the price of wheat reduces deficiency payments by $\$ 174$ million. Empirical studies suggest additionality of 10 to 30 percent. Therefore an EEP of 20 million tons adds 2 to 6 million tons to U.S. export demand. With a $\$ 50 / t o n$ bonus level, the budget outlays for the EEP are $\$ 1$ billion annually (recent levels). The 2 to 6 million ton increase in exports causes the wheat price to rise 20 to 60 cents per bushel and hence budget outlays to decline $\$ 350$ to $\$ 1050$ million annually. Thus, if the high end of additionality pertains, which is what USDA assumes, the EEP is budget neutral.

Earm Income and Consumer Welfare Effects. The main losses from the Export Enhancement Program accrue to domestic buyers of U.S. wheat. The exact incidence on the buyers' side - among farmers who feed wheat, millers, bakers, retailers, and final consumers has not been estimated. Because domestic final demand for foods containing wheat is quite inelastic, domestic consumption of these products is unlikely to change appreciably because of the EEP, and in fact domestic use has been quite stable over time despite large changes in wheat prices. It is therefore unlikely that the EEP reduced the demand for, and thus the returns earned by processors, distributors or other middlemen. Certainly the evidence in the political debate is consistent with this cunclusion. Millers and bakers who took public positions favored the Export Enhancement Program (usually because they had export as well as domestic interests).

Farm use of wheat in feeding ranges from 5 to 20 percent of U.S. production. Wheat feeding is highly concentrated in the late summer months after winter wheat is harvested but 
before the fall corn harvest, especially when year-end stocks of feed grains are low and old-crop prices high. Generally, livestock producers who use this wheat have very good substitutes in other feeds, so that feed use practically disappears in high-price years.

With an elasticity of demand for feed wheat of -4 , the Export Enhancement Program drives up the U.S. price of wheat 10 percent ( 35 cents per bushel), and if livestock prices do not rise so that livestock producers absorb the feed cost increase, the expected cost of the EEP to the livestock industry is about $\$ 100$ million annually. To the extent meat prices rise, the cost is shifted to consumers.

The remainder of the cost of higher wheat prices is absorbed by consumers of bread, breakfast cereals, bakery products and other food items containing wheat.

USDA's economic analysis, which is the basis for OMB's budget work on EEP, uses a model which provides estimates of farm income gains and consumer costs of EEP. The model estimates that an increase of 10 cents per bushel in the price of wheat raises farm income by $\$ 60$ million and reduces consumers' surplus by $\$ 120$ million (Salathe, 1991). The consumer cost estimate assumes farm price increases for all domestically used wheat are passed on to consumers without any change in the farm-to-consumer markup or profits in the wheat processing industry. The farm income increase is only about one-fourth of the rise in the market value of the wheat crop because three-fourths of wheat production is protected by deficiency payments which decline cent for cent as the market price rises. ${ }^{25}$

\footnotetext{
${ }^{25}$ This assumes the price rise cocurs in the 5-month peak marketing season. In the 1990 Farm Act, in any case, the calculation of deficiency payments was changed to a full-year basis after 1993. Since the full-year price averages 10 cents per bushel above the 5-month price, and the payment will be determined by the maximum of the full-year price or the 5-month price plus 10 cents, this change was scored as a budget saving (about $\$ 120$ million a year) in the 1990 Budget
} 
The overall domestic welfare effect of the EEP can be estimated by summing the budget, consumer and producer changes if we assume the farm income change is a change in economic rents (i.e., farmland and farm operator labor as taken as fixed in supply). For the range of additionality of .1 to .3 , the EEP at its average recent size of about 20 million tons and cost of $\$$ I billion annually, generates the results shown in table 6. While an optimistic assumption of additionality permits EEP to achieve the objective of budget neutrality, no assumption permits the program to achieve its cost-effectiveness objective of providing a benefit to the U.S. economy. ${ }^{26}$ Indeed, the EEP is a particularly inefficient income transfer program by these estimates, generating almost $\$ 1$ in deadweight losses (from the U.S. viewpoint) for each $\$ 1$ of farm income gain even under optimistic additionality assumption.

Intemational Effects. Political discussion of the Export Enhancement Program from its inception emphasized the effects abroad as well as domestic effects in the United States. The Bush Administration in 1989 and Congress in its reauthorization of EEP in 1990 focused even more sharply on the foreign effects. The Food, Agriculture, Conservation and Trade (FACT) Act of 1990 , which authorizes the EEP at a level of not less than $\$ 500$ million annually and explicitly authorizes cash as well as in-kind subsidies, gives the only purpose of the EEP as being "to

Reconciliation Act negotiations.

${ }^{26}$ If such calculations are to be used in budget planning, one should also consider the ARP as an alternative policy instrument. This is not a counterfactual exercise in the way invoking a lump-sum transfer as an alternative policy would be. The ARP is in fact adjusted annually. The Congressional Budget Office has argued that it would be preferable to reduce wheat acreage rather than grow wheat and subsidize its export. Assuming 3 additionality, the same deficiency payment farm income, and consumer costs as in the right hand column of table 6 could be achieved with a paid land division program that would cost about $\$ 400$ million (for 8 million acres) instead of the \$I billion EEP subsidy cost. 
Table 6. Economic Gains from the EEP

\begin{tabular}{lcc}
\hline Additionality & .1 & .3 \\
& & -- million dollars annually-- \\
Cost of EEP subsidies & -1000 & -1000 \\
Deficiency payment reduction & 350 & 1050 \\
[Subtotal: budgetary gain & -650 & 50 \\
Crop producers' income gain & 120 & 300 \\
Livestock feeders' gain & -40 & -100 \\
Consumers' gain & -200 & -500 \\
Total U.S. gain & -770 & -250 \\
\hline
\end{tabular}

Source: Salathe (1991), and calculations described in text. 
discourage unfair trade practices" (U.S. House, 1990, p. 335). The context for this focus was the continued expansion of the European Community's subsidized exports and the EC's intransigence on agriculture in the Uruguay Round, then scheduled for completion in December 1990. The Omnibus Budget Reconciliation Act, enacted in October 1990 along with the Farm (FACT) Act, contained a "GATT trigger" which required spending $\$ 1$ billion annually on EEP if no Uruguay Round agreement had been reached by June 30, 1992. Since no agreement had been reached at that time, EEP spending has proceeded at about the $\$ 1$ billion rate. ${ }^{27}$

The international effects of the EEP are impossible to estimate with precision. Uncertainties about effects on other countries' exports and on world prices are even greater than in estimates of U.S. export additionality. The intention of targeted EEP subsidies is to displace EC subsidized exports and increase the cost of EC export subsidies, yet not displace the exports of non-subsidizing exporters. If perfectly realized, the result would be no change in worldwide wheat imports, no change in (nonsubsidized) world wheat prices, but a rise in the U.S. wheat price and wheat exports, and a fall EC wheat exports achieved by increased stocks and reduced acreage in the EC.

In fact, the EC would be expected to respond by reducing acreage, as they have done, but also by countering EEP subsidies with increased subsidies of their own, thus retaining part of the market. This competition would be likely to remove the intramarginal nature of the subsidized price in importing countries and reduce the price of all wheat in these contested markets.

\footnotetext{
${ }^{27}$ The wheat EEP activity shown in table 2 accounts for most of U.S. agricultural export subsidies, but EEP bonuses have also been paid for exports of feedgrains, vegetable oil, rice, eggs, frozen poultry, and dairy cattle. In FY 1992, total EEP bonuses were \$966 million, of which $\$ 838$ million were for wheat and wheat flour.
} 
Therefore, total wheat imports in these countries should increase. The best markets in which to observe the consequences of the subsidy war are the North African wheat importers (Egypt, Algeria, Morocco, Tunesia, and Libya), traditional buyers of French wheat and flour which were the first and largest EEP targets (except Libya) and whose imports account for about 15 percent of world wheat trade. Aggregate wheat imports in these countries have increased since 1985. Indications are that North African buyers - principally government-related enterprises with substantial market power locally — have filled their needs via tenders and bargaining which results in all suppliers, the EC, U.S., Canada, Australia, and (in Libya) Argentina selling for comparable prices (Ackerman, 1993; Parker, 1990). So the nonsubsidizing suppliers are being harmed as well: the Canadian and Australian Wheat Boards have to subsidize their sales in these markets also.

A question can also be raised about the capability of separating targeted and nontargeted countries. Why would nontargeted countries keep buying at nonsubsidized prices? Even if reexports from, say, Morocico to Korea are ruled out by transportation costs, Australian exports could easily be redirected from North Africa to Korea if the price were higher in Korea. So we should expect to see wheat prices falling worldwide, except inside the U.S. and EC. Other countries' wheat exports should be replaced by U.S. and EC wheat in importing countries where the U.S. and EC compete, while competing exporters should increase their market share in countries where the U.S. and EC do not offer subsidies. Such shifts have in fact cxcurred, but nonetheless the United States has retained the ability to export about half its wheat without EEP subsidies (although most of this has credit subsidies or is shipped in the P.L. 480 fond assistance 
programs). Notably, Japan continues to buy about 3 to 5 million metric tons of U.S. wheat annually (10 - 15 percent of U.S. exports) at non-subsidized prices. ${ }^{28}$

Data on wheat border prices in several countries are shown in Figure 9. The EEP, if effective, should have increased the U.S. price, from which the subsidy is subtracted and transportation added to obtain the importing buyer's price. And, if the EEP affected other countries' prices it should have reduced them. Comparing two U.S. prices (Kansas City and U.S. Gulf) with Canada, Australia, and Rotterdam price, no such pattern is apparent. Of course, the levels of price everywhere are determined more by world crop conditions, U.S. ARPs, and macroeconomic factors than by the EEP. But none of these factors would place a wedge between U.S. and other exporters' wheat prices in the way the EEP might do. Yet, to take a long-term comparison, the difference between the U.S. Kansas City price and the Argentine, Canadian, Rotterdam, and Australian prices are largely the same in 1984 with no EEP and in 1992, with an average EEP bonus of $\$ 40$ per ton. Indeed, if there is a difference it is that the U.S. prices fell relative to the foreign prices.

The data are more consistent with the hypothesis that the EEP drove down the price of wheat in the targeted importing countries, with all the competing exporters who remained in those markets offering matching subsidies, while prices in the remaining markets were mutually determined by spatial market forces which are basically the same as with no EEP. If this is true,

\footnotetext{
${ }^{26}$ Taking Japan as an importer with inelastic demand while other importers have relatively elastic demand and exporters inelastic supply, we have an approximation (if other exporters cooperate) of the situation shown by Dutton (1990) to create the possibility of targeted export subsidies being a second-best mechanism for exporters to exercise monopoly power. This result would show up empirically as an increase in the U.S. price of wheat for a given level of imports (as U.S. wheat is reallocated from elastic-demand to inelastic-demand markets). Empirical evidence that this has occurred is lacking.
} 
FIGURE 9. World Wheat Prices

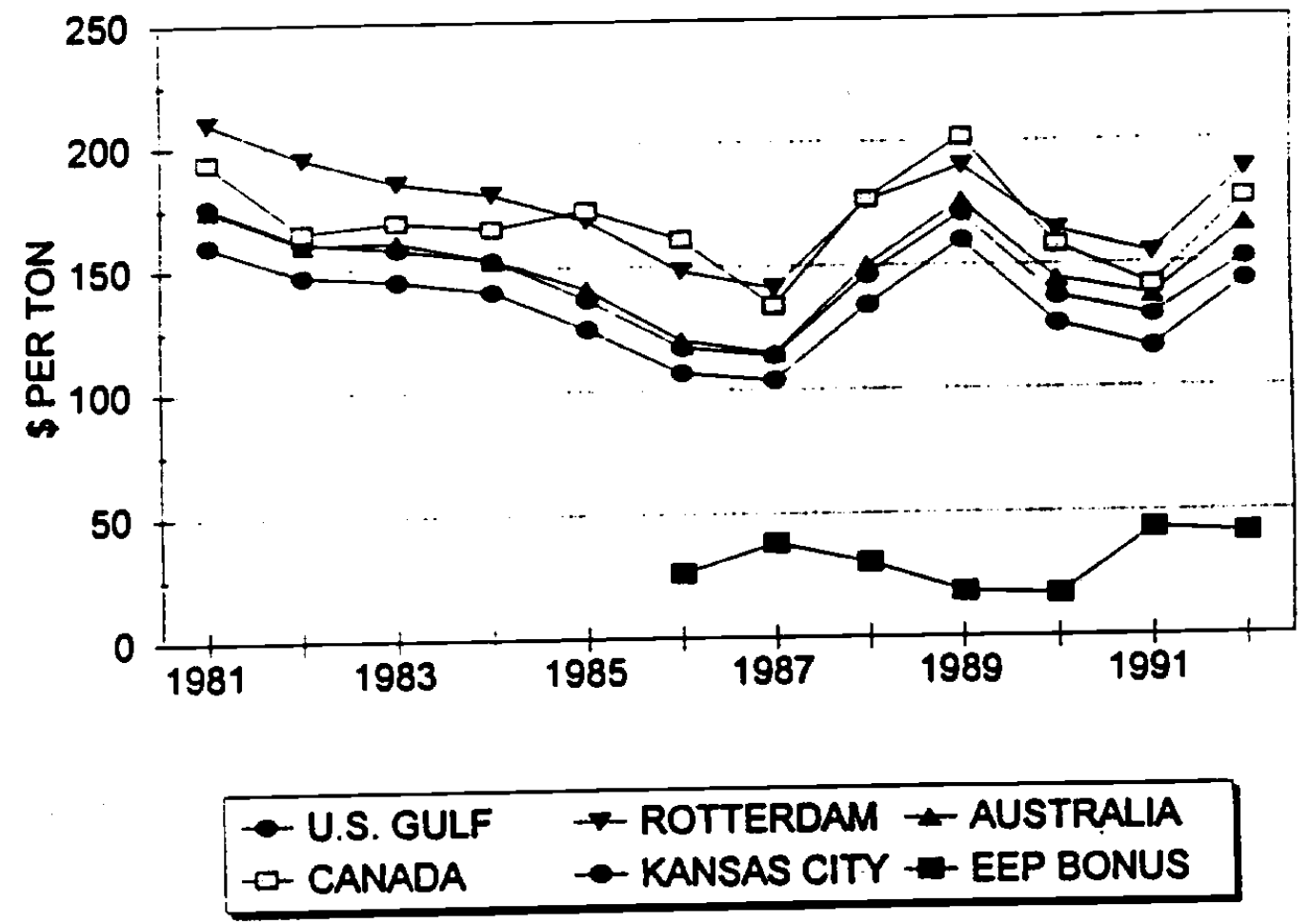


the economic effects of the Export Enhancement Program are at the low end of the ranges given in Table 3, perhaps even lower.

The price relationship most crucial to the essentially null-effect interpretation of EEP effects is that between the U.S. and Canada. If the EEP were to place a $\$ 30$ to $\$ 50$ wedge between U.S. and Canadian prices for a period of 8 years there would be tremendous pressure to export Canadian wheat to the United States. In fact, such pressure in the past has led to the imposition of import quotas under the "section 22" authorities described earlier. But section 22 import quotas were removed by Executive Order in 1974 and have never been reinstated.

In 1992 and 1993 there has at last occurred a surge of wheat imports from Canada, about 2 million tons each year. This is a quadrupling of such imports compared to the 1980-1990 average. Yet as a percentage of either Canadian or U.S. wheat exports, the amounts are quite small (refer back to figure 2). It is noteworthy also that much of these imports are of durum wheat, a type used primarily in making pasta, and grown in the United States predominantly in North Dakota and in Canada just across the border. The price of durum wheat moves rather independently of other wheats.

The U.S. International Trade Commission investigated the Canadian exports of durum wheat to the United States in response to Congressional requests. Their report (USITC, 1990) attributes these exports in part to the Export Enhancement Program driving down the price of durum wheat in the markets to which Canada has traditionally been exporting this product. Since the ITC report, durum imports from Canada have increased substantially, from about 0.2 million metric tons annually to 0.7 million tons in 1992/93. U.S. durum exports have continued at about 
1.5 million tons annually during this period, with the majority receiving EEP subsidies in the range of $\$ 25-\$ 50$ per ton. In 1992, U.S. durum exports under EEP were 0.9 million tons, with an average bonus of $\$ 42.50$ per ton (Alston and Carter, 1993). This would appear a clear case of the EEP creating a wedge between U.S. and Canadian prices, so that durum wheat going out through the front door (to North Africa and South America) comes back in through Canada. The picture is complicated, however, by the facts that U.S. durum wheat in 1992 had declined in price since 1989, sold at a lower price than average wheat in the U.S., and that U.S. durum wheat acreage and production declined in 1992 by roughly the amount of the increased Canadian shipments to the United States. The National Association of Wheat Growers has cited the data of table 4 as showing a lack of correlation between U.S. durum exports under EEP and Canadian wheat exports to the United States.

The economic analysis carries political freight because if the imports are attributable to autonomous Canadian policies rather than being caused by the EEP, the case is better for imposing section 22 import quotas. The case to be made is that Canadian exports interfere with the operation of the U.S. wheat program. These imports can be argued to have increased the cost of the program by driving up deficiency payments slightly, but whether this argument is legally sufficient remains to be determined. In the course of the NAFTA debate, the Clinton Adminstration promised an inquiry into the matter, which the ITC subsequently undertook but as of March 1994 was incomplete. In addition to the general section 22 issue, there is a question whether such quotas applied to Canada would violate the U.S./Canadian Free Trade Agreement. Section 22 quotas are global quotas but exempting Canada would nullify their effectiveness. 
Table 4. Data on Wheat Trade Between Canada and the United States

$\begin{array}{ccc}\begin{array}{c}\text { U.S. EEP Sales } \\ \text { of Durum Wheat }\end{array} & \text { Canadian Durum } & \text { All Canadian } \\ \text { Exports to the } & \text { Wheat Exports } \\ \text { (Worldwide) } & \text { United States } & \text { to the U.S. }\end{array}$

Crop Year

(July-June)

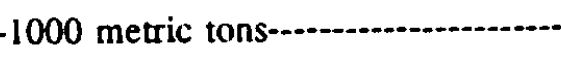

$1985 / 86$

50

0

280

$1986 / 87$

1122

59

417

$1987 / 88$

942

177

320

$1988 / 89$

187

191

285

$1989 / 90$

700

173

379

1990/91

990

330

547

$1991 / 92$

673

393

858

1992/93

895

420

1320

Source: National Association of Wheat Growers 


\section{Political Response to the EEP}

In 1990 the legislation authorizing the EEP (and other farm programs) expired and was reconsidered in a comprehensive set of hearings (U.S. House, 1991; U.S. Senate, 1991). This provided a convenient opportunity for interest groups to express second thoughts and suggested modifications of the EEP. The National Association of Wheat Growers, as well as representatives of other commodities using the program, were totally supportive of continuation of the EEP without substantial change. Concerns that had been expressed in the 1985 House hearings about targeting as opposed to a generally available subsidy disappeared. Grain users might have been expected to be more critical, but more of them supported EEP in 1990 than had in 1985. The American Bakers Association, the Biscuit and Cracker Manufacturers' Association, and the North American Export Grain association all testified in favor of continuing the program.

Grain exporters asked for changes in the procedures by which export bonuses are awarded, which would give the companies greater flexibility in making deals with importers (U.S. Senate, 1991, Part XIII). This however was the one area where concerns had been expressed by nonfarm and some farm groups - that the program was too friendly to exporting companies and that these companies rather than farmers were profiting from the program. This concern persists to the present, as exemplified in the recent New York Times series on "Tainted Trade," the first installment of which was headlined on p. 1: "Abuses Plague Programs to Help Exports of Agricultural Products" (New York Times, October 10, 1993). None of the particular abuses cited - and substantively there were not many - involved the wheat EEP program..$^{29}$ in

\footnotetext{
${ }^{29}$ The two main abuses were tobacco export assistance (not under EEP) that subsidized exports by U.S. tobacco companies of foreign grown leaf, and corruption (Iraq allegedly using ostensibly grain import credit to buy arms) in the sale of rice to Iraq in the period leading up to
} 
addition, economists have continued to assert, based on arguments and analysis discussed earlier, that the EEP generated few benefits to farmers for its costs.

Because of firm support from commodity and agribusiness groups, and weak opposition, the EEP emerged unchanged in structure and strengthened in budget in the 1990 Farm Act. EEP spending was far higher in FY91-93 than in any previous 3-year period (Table 5). The solid political support was attributable not so much to particular export achievements of the EEP, but to farmers' general satisfaction with the recovery of farm income from mid-1980s lows and the role of the commodity programs in that recovery. CCC wheat inventories had been sold off, deficiency payments protected producers from low prices in 1986, the export market had recovered with the dollar's decline from its 1985 high, and reduced output boosted wheat prices back to 1980-81 level in 1989 and 1990. Farm interests in the 1990 farm bill debate were devoted mainly to attempting to forestall the budget cuts of about $\$ 2$ billion annually that the Bush Administration was calling for. The EEP was thus seen as a piece of a set of programs that was working. Beyond general satisfaction with the situation, ${ }^{30}$ a principal threat to U.S. grain producers was seen to be EC subsidized exports. The EEP was seen as particularly valuable in this situation, with the Uruguay Round languishing.

Opposition to EEP was mitigated because farm bill reformers focused on other policies. The only organized reform effort, by a coalition of conservative Republicans and urban

the invasion of Kuwait in 1990.

${ }^{30}$ It may be thought that farmers' positive attitude is being overstated in view of the complaints of many farm witnesses and the gloomleading of many Agriculture Committee members. Evidence that this was aimed at forestalling cuts rather than changing programs is the absence of major proposed changes in the 1990 debate. Recall too that President Bush won the farm vote in 1992 (see Conk, Art, and Evans). 
Democrats in the House of Representatives, brought to the floor of the House amendments to reduce or eliminate the sugar, wool, and honey programs, and eliminate deficiency payments to farms with over a million dollars in sales or to farmers who earned more than $\$ 100,000$ from offfarm sources. These amendments all failed. These had more apparent popular appeal than an anti-EEP amendment would have; this helps explain why none was offered.

A second important factor mitigating opposition to EEP was its being scored as budget neutral. The reforms that were successful in the 1990 Farm Act, most notably the introduction of a 15 percent reduction in deficiency payments by making 15 percent of each producer's base acreage ineligible for payments, was driven by the budget reconciliation agreement to cut $\$ 13$ billion from farm program spending over the five fiscal years 1992-96. The $\$ 1$ billion annual spending on EEP would have been a prime target for cuts if the program had not been scored as budget-neutral by OMB.

Since passage of the 1990 Farm Act the EEP has become politically still stronger and further entrenched. Recently EEP sales have been extended to Mexico. The GATT triggers have locked a minimum of $\$ 1$ billion annually into EEP bonuses. The Canadian government has objected to this program on several occasions. When President Bush was planning his visit to Australia in 1991, the White House found to their surprise that the lead item for discussion between the heads of state, in the Australian view, was U.S. wheat exports under the EEP.

The desired route to demise of the EEP would be a successful conclusion of the Uruguay Round with agriculture included along the lines of the "Blair House" agreement reached between the U.S. and EC in December 1992. One of the few substantive changes in U.S. policy that Blair House requires is a phase-down of the EEP. In the end, this program could be considered a 
success in the same vein as President Reagan's arms buildup in promoting nuclear weapons agreements with the USSR. Even if no Uruguay Round agreement on agriculture is reached it still noteworthy that the EC has in 1991-93 introduced significant reforms of the Common Agricultural Policy, including acreage set-aside and other measures to reduce outlays on their export subsidies. The strength of U.S. willingness to spend on EEP quite likely had a role in encouraging these reforms, though how important a factor is unclear. ${ }^{31}$

\section{Conclusions}

A summary of interest group positions on the EEP, and how they fared, is shown in Table 7. The most active group, wheat producers, were substantial economic gainers from the program. Wheat exporting businesses were less active but were also supportive of EEP, and were winners. Other agricultural producers, notably feed grains, gained by obtaining a piece of the EEP action and also supported the program. The losing groups-domestic grain processors and consumers-did not visibly oppose the program.

${ }^{31}$ What is the U.S. gain from CAP reform? Although it is even more conjectural than the earlier calculations, CAP reform along the lines being implemented could well reduce EC wheat exports by 3 to 4 million tons annually, and raise the U.S. market price by 20 to 30 cents per bushel. The resulting gain for U.S. producers would be $\$ 120$ to $\$ 180$ million annually, and the gains to taxpayers would be $\$ 350$ to $\$ 520$ million (because of less deficiency payments). U.S. consumers would lose $\$ 240$ to $\$ 360$ million. The overall net gain to the United States, equal roughly to the price increase times wheat exports, would be $\$ 230$ to $\$ 350$ million.

Suppose the EEP accelerated CAP reform by five years. Then the EEP generated $\$ 1.1$ to $\$ 1.8$ billion for the United States. The overall U.S. cost of the EEP in 1990-92, using a midpoint value from table 3, was $\$ 510$ million annually, or about $\$ 2$ to $\$ 3$ billion for 1986-1993. These calculations are of course crude, but they indicate that it is quite difficult to obtain any net U.S. gain from EEP as a strategic investment, even under the assumption that it successfully induced policy changes in the EC. 
Table 7. Interest Groups' Positions on the Export Enhancement Program, 1985 Congressional Debate
Support
Inactive
Opposed

$\begin{array}{llr}\text { Most } & \text { Least } & \text { or } \\ \text { Active } & \text { Active } & \text { Neutral }\end{array}$

Winners

Wheat producers $\mathrm{X}$

Wheat exporters $\quad \mathrm{X}$

Rice, Feed Grains and Other

EEP-eligible furmers $\quad \mathrm{X}$

Custom wheat harvesters

and input supplies

$\mathrm{X}$

Mixed or No Effect

General Farm Organizations $\mathbf{X}$

Millers*

$X$

\section{Losers}

Consumer groups

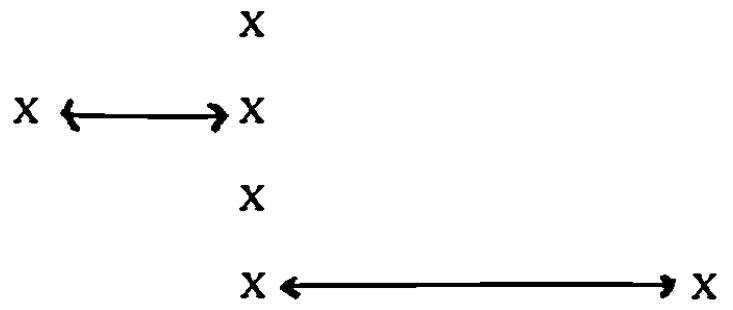

Public-Interest Watchdogs**

* Millers were not all losers because subsidies are paid for some flour as well as wheat exports.

** Principally op-ed columnists and other authors. 
The most striking feature of the political economy of the Export Enhancement Program is how little impact standard economic arguments have had. Economists have produced many analyses showing that the program, even as a second-best measure, generates a net loss to the U.S. economy, although some have muddied the waters by showing that a precisely calibrated system of country-specific export subsidy rates could be welfare-increasing if the U.S. has varying degrees of monopoly power in different wheat import markets (e.g., Abbot, Paarlberg, and Sharples, 1987). The lack of clout of the overall U.S. welfare argument is not surprising given the prevalence of government activity that generates deadweight losses in order to redistribute income.

It is perhaps more surprising that fact-based analyses that argued farmers as well as the rest of the economy would be better off under alternative policies did not cut more ice politically (e.g., Paarlberg, 1988). It seems clear in retrospect that for such an argument to be effective it has to be accepted by farmers themselves as well as by disinterested observers. The Agriculture Committees take their cue first and foremost from farmers, and if farmers are united only very strong opposition can be effective.

In order for wheat growers to abandon EEP, they would have to be shown how they could be made just as well off with alternative policies that are politically feasible. The option of cutting acreage with an increased ARP causes farm income to be lower for a given price of wheat because of the opportunity cost of idled acres. Political feasibility also means avoiding the one nonfarm source of strong opposition, objection to increased budget outlays. This rules out the standard approach that economists offer, nondistorting or less distorting transfer payments. With acreage and yield bases fixed, and farmers free to plant alternative program crops without 
affecting their payments, increasing the wheat target price would provide payments not far from being a nondistorting transfer (apart from the marginal cost of raising government funds). But budgetary pressure makes this a non-starter.

The biggest losers from the Export Enhancement Program are buyers of wheat, with losses of $\$ 250$ to $\$ 600$ million per year according to estimates presented earlier, with recent world price data suggesting the Jower end of the range is more likely. But no buyers of wheat - millers, bakers, livestckck producers, or consumers of retail products containing wheat - have raised politically significant objections to the program. Agribusiness interests probably did not bear any losses. Livestock feeders' costs have not been substantial, and a feeling of solidarity along with logrolling keeps them from opposing the program. ${ }^{32}$ Consumer costs are only about $\$ 1$ to 3 per year per person; and the general public remains generally supportive of farmers according to polls.

In short, the Export Enhancement Program has proved a political winner because:

- wheat producers see a benefit from it

- wheat producers have a unified view on the issue, and they have effective channels of influence through the Congressional Agriculture committees

- wheat buyers have not opposed the program

- the program has been accepted as budget neutral

\footnotetext{
${ }^{32}$ Livestckck producers do not have price support programs but logrolling can occur because cattle feedlots get lower priced feeder calves when grazing costs are lower, so cattle interests need crop producers' support on keeping Federal grazing fees low; and poultry products have been exported under EEP using CCC grain as a source of bonuses, so the poultry industry has an interest in the EEP.
} 
There are two points of vulnerability for the Export Enhancement Program in the near future. The first is in the budgetary arena. Budget neutrality arguments are becoming less plausible now that CCC stocks are no longer used as bonuses, and apparent effects on U.S. prices are small. The second point is that a GATT agreement in agriculture along the lines of the Blair House Agreement between the U.S. and EC would require a reduction of EEP. This places EEP reform as part of a policy package that would make U.S. farmers as well as nonfarmers better off than at present. 


\section{References}

Abbot, P.C., Paarlberg, P.L. and J.A. Sharples. "Targeted Agricultural Export Subsidies and Social Welfare," American Journal of Agricultural Economics, 69 (Nov. 1987): 723-732.

Ackerman, Karen Z. "The Moroccan Wheat Market," Wheat Situation, USDA-ERS, WAS-303, Sept. 1993, pp. 22-25.

., and Mark E. Smith. "Agricultural Export Programs," USDA, Economic Research Service, Staff Report No. AGES 9033, May 1990.

Alston, Julian M., and C.A. Carter. "Effects of Farm Programs on Gains from Canada-U.S. Wheat Trade," Canadian Ag. Econ. Meetings, Edmondton, July 1993.

Amstutz, Daniel G. "Prepared Statement" in U.S. House, 1986, pp. 141-144.

Anania, Giovanni, Mary Bohman, and Colin A. Carter. "U.S. Export Subsidies in Wheat," Americian Joumal of Agricultural Economics 74 (August 1992): 534-545.

Bailey, Kenneth W., and James P. Houck. "A Dynamic Assessment of the Wheat Export Enhancement Program," North Central Journal of Agricultural Economics 12 (July 1990): $319-332$.

Benedict, Murray R. Farm Policies of the United States. 1790-1950, New York: The Twentieth Century Fund, 1953.

Bohman, M., C.A. Carter, and J.H. Dorfman. "The Welfare Effects of Targeted Export Subsidies," American Journal Agricultural Economics 73 (1991): 693-702. 
Bonnen, James, and W.P. Browne. "Why Is Agricultural Policy So Difficult to Reform?" in

Carol Kramer, ed., The Political Economy of U.S. Agriculture, Washington, D.C.:

Resources for the Future, 1989, pp. 7-33.

Brooks, H.G., S. Devadoss, and W. H. Meyers: "The Impact of the EEP on the World Wheat Market," American Journal of Agricultural Economics 38(1990): 253-277.

Chambers, Robert G., and P.L. Paarlberg. "Are More Exports Always Better? Comparing Cash and In-kind Export Subsidies," American_Journal_of_Agricultural Economics 73(1991): 142-154.

Cook, Kenneth A., Andrew B. Art, and Molly C. Evans. "Bush Defeats Clinton! An Analysis of 1992 Election Results in Farming-Dependent Counties," Center for Resource Economics, Washington D.C., November 1992.

Davison, Cecil W., and Carlos Arnade. "Export Demand for U.S. Corn, Soybeans, and Wheat," USDA, ERS, Tech. Bul. No. 1784, Jan. 1991.

Dixit, A.K., and V. Norman. Theory of International Trade, Digswell Place, Welwyn: Nisbet/Cambridge, 1980.

Dutton, John. "Targeted Export Subsidies as an Exercise of Monopoly Power," Canadian Journal of Economics 23(1990): 705-710.

Dutton, John, and Thomas Grennes. "Measurement of Exchange Rates Appropriate for International Trade," Dept. of Econ., N.C. State Univ., Econ. Res. Report No. 51, Nov, 1985. 
Gallagher, Paul, M. Lancaster, M. Bredahl, and T. Ryan." The U.S. Wheat Economy in an International Setting," U.S. Dept. of Agriculture, Econ. Research Service, Tech. Bul. No. 1644, March 1981.

Gardner, Bruce L. "Agricultural Policies: United States," in F.H. Sanderson, ed., Agricultural Protectionism, Washington, D.C.: Resources for the Future, 1991, pp. 19-63.

"Causes of U.S. Farm Commodity Programs," Journal of Political Economy 95 (1987): $290-310$.

Guither, Harold D. "Tough Choices: Writing the Food Security Act of 1985," American Enterprise Institute Occasional Paper, Washington, D.C., December 1986.

Hardin, Charles M. "Farm Politics and the Separation of Powers," in R. J. Hildreth, ed., Readings in Agricultural Policy, Lincoln: Univ. of Nebraska Press, 1968, pp. 69-77.

Houck, James P. "The Basic Economics of an Export Bonus Scheme," North Central Journal of Agricultural Economics 8(July 1986): 227-235.

Itoh, Motoshige, and Kiyomo Kazuharu. "Welfare-enhancing Export Subsidies," ournal of Political Economy 95(Feb. 1987): 115-137.

Johnson, D. Gale. "Agriculture and U.S. Trade Policy," in U.S. Senate, 1984b, pp. 157-168.

Lin, William, and Bruce Gardner. "Aggregate Effects of Commodity Programs," mimeo, USDAERS, 1988.

National Corn Growers Association. "News Release," Washington D.C., August 15, 1985.

Organization for Economic Cooperation and Development (OECD). National Policies and Agricultural Trade, Paris: OECD, 1987. 
Agricultural Policies. Markets and Trade, Paris: OECD, 1991.

O'Rourke, Desmond A. "Taking Account of Competitive Realities," in U.S. Senate, 1984b, pp. 119-123.

Paarlberg, Robert L. Fixing Farm Trade, Cambridge, Mass.: Ballinger, 1988.

Parker, John B. "U.S.-EC Competition in North Africa Wheat Market," Wheat Situation, USDAERS, WAS-290, August 1990, pp. 36-38.

Rapp, David. How the U.S. Got Into Agriculture, and Why It Can't Get Out. Washington, D.C.: Congressional Quarterly Inc., 1988.

Salathe, Larry. "Budget Neutrality of EEP," USDA, Economic Analysis Staff, mimeo, November, 1991.

Schwensen, Carl. "The United States - A Major Wheat Producer and Exporter," in U.S. Senate, 1984a pp. 24-31.

Seitzinger, A.H., and P.L. Paarlberg. "The Export Enhancement Program," USDA, ERS, Agr. Inf. Bul. No. 575, 1989.

- "A Simulation Model of the U.S. EEP,"American Journal of Agricultural Economics 72 (1990): 95-103.

Sharples, Jerry A. "The Short-run Elasticity of Demand for U.S. Wheat Exports," USDA-ERS, Staff Report AGES 8200406, April 1982.

. "Are Export Subsidies the Answer to U.S. Grain Surpluses?", in U.S. Senate, 1984b, pp. 176-186.

Tosterud, Robert J. "Perspectives on International Trade from Former Secretaries of Agriculture," in U.S. Senate, 1984b, pp. 320-322. 
U.S. Congress. Congressional Budget Office. "Reducing the Deficit: Spending and Revenue Options," Report to House and Senate Budget Committees, March 1994.

U.S. Department of Agriculture. "Former USSR," Economic Research Service, RS-93-1, May 1993.

U.S. General Accounting Office. "Wheat Support: The Impact of Target Prices Versus Export Subsidies,"Report to Congress, June 1994.

U.S. House of Representatives, Committee on Agriculture. General Farm Bill of 1985, Hearings March-May 1985, Parts 1, 5, U.S. Govt. Printing Office. Report to Accompany H.R. 2100: Food Security Act of 1985, Rpt. 99-271, part 1, Sept. 13, 1985.

Review of the EEP, Hearings Oct. - Nov. 1985, 99-16, US GPO, 1986.

- Formulation of the 1990 Farm Bill, Parts 1-14, U.S. GPO, 1991.

- Conference Report to Accompany S. 2830, Report 101-916, Oct. 22, 1990.

U.S. International Trade Commission. "Durum Wheat: Conditions of Competition Between the U.S. and Canadian Industries," Washington, D.C. USITC Pub. 2274, June 1990.

U.S. Senate, Committee on Agriculture, Nutrition, and Forestry. Earm Policy Perspectives: Setting the Stage for 1985 Agricultural Legislation, Washington: U.S.

Government Printing Office, April 1984 (a). Trade Policy Perspectives, U.S. GPO Dec. 1984 (b). - Agricultural Export Trade, S. Hrg. 98-70, U.S. GPO, Feb. 1983. . Examining the Competitive Position of U.S. Agriculture, S. Hrg. 99-57, Feb.

$7,1985$. 
Framework and Analysis for Agricultural Policy in 1985, S. Hrg. 99-55, March

1985.

Reauthorization of the Agriculture and Food Act of 1981, S. Hrg. 99-115, parts

I \& II, March-April, 1985.

Preparation for the 1990 Farm Bill, Parts I - XV, US GPO, 1991.

polec.wp/ehw/4-13-94 